\title{
Allowable Residual Contamination Levels in Soil for Decommissioning the Shippingport Atomic Power Station Site
}

W. E. Kennedy, Jr.

B. A. Napier

J. K. Soldat

September 1983

Prepared for the U.S. Department of Energy under Contract DE-AC06-76RLO 1830

Pacific Northwest Laboratory

Operated for the U.S. Department of Energy

by Battelle Memorial Institute 


\title{
DISCLAIMER
}

This report was prepared as an account of work sponsored by an agency of the United States Government. Neither the United States Government nor any agency thereof, nor any of their employees, makes any warranty, express or implied, or assumes any legal liability or responsibility for the accuracy, completeness, or usefulness of any information, apparatus, product, or process disclosed, or represents that its use would not infringe privately owned rights. Reference herein to any specific commercial product, process, or service by trade name, trademark, manufacturer, or otherwise, does not necessarily constitute or imply its endorsement, recommendation, or favoring by the United States Government or any agency thereof. The views and opinions of authors expressed herein do not necessarily state or reflect those of the United States Government or any agency thereof.

\author{
PACIFIC NORTHWEST LABORATORY \\ operated by \\ BATTELLE \\ for the \\ UNITED STATES DEPARTMENT OF ENERGY \\ under Contract DE-AC06-76RLO 1830
}

\begin{tabular}{|c|c|}
\hline \multicolumn{2}{|c|}{$\begin{array}{c}\text { National Technical Information Service } \\
\text { United States Department of Commerce } \\
5285 \text { Port Royal Road } \\
\text { Springfield, Virginia } 22161\end{array}$} \\
\hline \multicolumn{2}{|c|}{$\begin{array}{l}\text { NTIS Price Codes } \\
\text { Microfiche A01 }\end{array}$} \\
\hline \multicolumn{2}{|c|}{ Printed Copy } \\
\hline Pages & $\begin{array}{l}\text { Price } \\
\text { Codes }\end{array}$ \\
\hline 001-025 & $\mathrm{A} 02$ \\
\hline $026-050$ & $\mathrm{~A} 03$ \\
\hline $051-075$ & $\mathrm{~A} 04$ \\
\hline $076-100$ & A05 \\
\hline $101-125$ & $\mathrm{~A} 06$ \\
\hline $126-150$ & $\mathrm{~A} 07$ \\
\hline $151-175$ & $A 08$ \\
\hline $176-200$ & $A 09$ \\
\hline $201-225$ & $\mathrm{~A} 010$ \\
\hline $226-250$ & $\mathrm{~A} 011$ \\
\hline $251-275$ & $\mathrm{~A} 012$ \\
\hline $276-300$ & $\mathrm{~A} 013$ \\
\hline
\end{tabular}


ALLOWABLE RESIDUAL CONTAMINAT ION

LEVELS IN SOIL FOR DECOMMISSIONING

THE SHIPPINGPORT ATOMIC POWER

STATION SITE

W. E. Kennedy, Jr.

B. A. Napier

J. K. Soldat

September 1983

Prepared for the

U.S. Department of Energy

under Contract DE-ACO6-76RLO 1830

Pacific Northwest Laboratory

Richland, Washington 


\section{ABSTRACT}

As part of decomissioning the Shippingport Atomic Power Station, a fundamental concern is the determination of Allowable Residual Contamination Levels (ARCL) for radionuclides in the soil at the site. The ARCL. method described in this report is based on a scenario/exposure-pathway analysis and compliance with an annual dose limit for unrestricted use of the land after decommissioning. In addition to naturally occurring radionuclides and fallout from weapons testing, soil contamination could potentially come from five other sources. These include operations of the Shippingport station as a pressurized water reactor, operations of the Shippingport Station as a light-water breeder, overation of the nearby Beaver Valley reactors, releases during decommissioning, and overation of other nearby industries, including the Bruce-Mansfield coal-fired power plants. ARCL values are presented for 29 individual radionuclides and a worksheet is provided so that ARCL values can be determined for any mixture of the individual radionuclides for any annual dose limit selected. In addition, a worksheet is provided for calculating present time soil concentration values that will decay to the ARCL values after any selected neriod of time, such as would occur during a period of restricted access. The ARCL results are presented for both unconfined (surface) and confined (subsurface) soil contamination. The ARCL method and results described in this report provide a flexible means of determining unrestricted-use site. release conditions after decommissioning the Shippingport Atomic Power Station. 


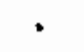


ABSTRACT

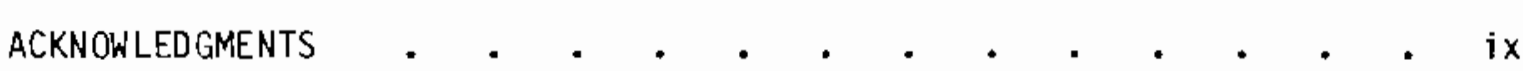

1.0 INTRODUCTION

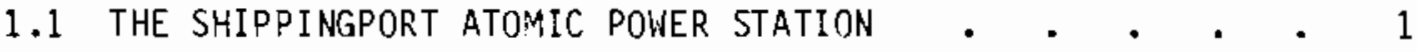

1.2 EXISTING DECOMMISSIONING STANDARDS . . . . . . . 3

1.3 HISTORY OF THE ALLOWABLE RESIDUAL CONTAMINATION

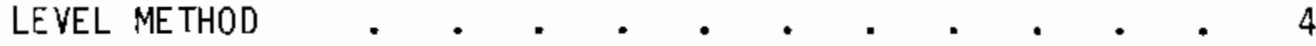

2.0 THE allowable Residual contamination level method . . . . 7

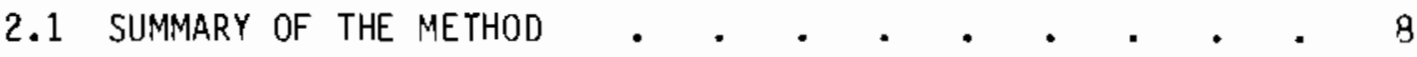

2.2 ALLONABLE RESiduAl CONTAMINATiON LEVELS • • • • • 10

2.2.1 Maximum Annual Dose . . . . . . . . 10

2.2.2 Radiation Exposure Pathway and Exposure Scenarios . 11

3.0 FACILITY DESCRIPTION

3.1 THE SHIPPINGPORT ATOMIC POWER STATION * . * * . 15

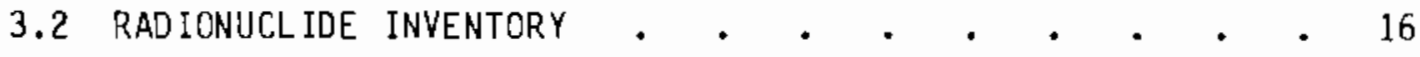

4.0 ARCL CALCULATIONS . . . . . . . . . . . . . . . . 21

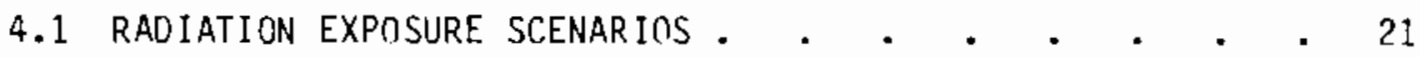

4.1.1 Residential/Home Garden Scenario . . . . . 21

4.1.2 Residential/Construction Scenario . . . . . 22

4.2 DOSE MODELS FOR RADIATION EXPOSURE PATHWAYS . • • . 23

4.3 ALLOWABLE RESIDUAL CONTAMINATIDN LEVEL MAXIMUM

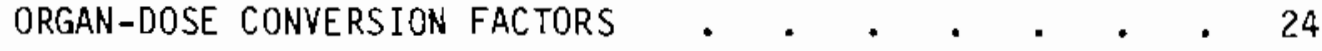


4.4 ALLOWABLE RESIDUAL CONTAIINATION LEVEL WORKSHEET FOR RADIONUCLIDES IN THE SOIL AT THE SHIPPINGPORT ATOMIC

POWER STATION

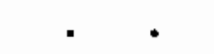

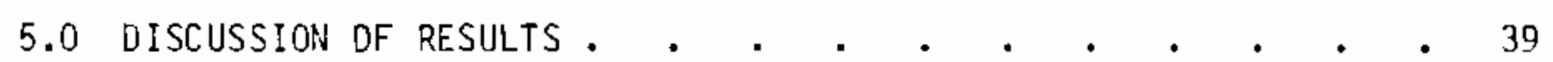

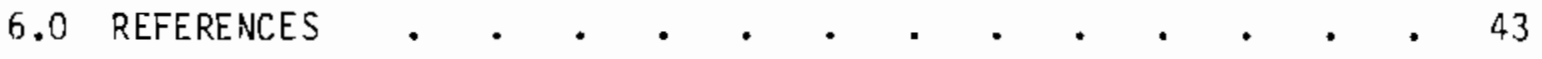




\section{LIST OF FIGIJRES}

1.1.1 Map Showing the Shippingoort Site . . . . . . . ?

2.1.1 Allowable Residual Contamination Leve1 Method Logic

Diagram . • • • • • • • • • • • • • • • • 9

3.1.1 Shippingport Station Site Plan . . . . . . . . 17

4.4.1 Allowable Residual Contamination Level Worksheet. for Soil Contamination at the Shippingport Atomic Power Station Site. . . . . . . . . . . . . 28

4.4.2 Al lowable Residual Contamination Level Worksheet for Soil Contamination at the Shippingport Atomic Power Station Site - Example Problem 1 . . . . . . .

4.4.3 Al lowable Residual Contamination Level Worksheet for Soil Contamination at the Shippingport Atomic Power Station Site - Example Problem 2 . . . . . . . . . 32

4.4.4 Allowable Residual Contamination Level Radioactive Decay Correction Worksheet. . . . . . . . . . 34

4.4.5 Allowable Residual Contamination Level Radinactive Decay Correction Worksheet - Example Prohlen 3 . . . . 36

4.4.6 Aliowable Residual Contamination Level Worksheet for Soil Contamination of the Shippingport Atomic Power Station Site - Example Problem 3 . . . . . . . 37

\section{LIST OF TABLES}

3.2.1 Dotential Radionuclides Accumulated on the Shippingport Site . . . . . . . . . . . . 19

4.3.1 Scenario-Suecific Allowable Residual Contamination Level Dose Conversion Factors for the Shippingport Atomic Power Station 
4.3.2 Allowable Residual Contamination Level Values for Individual Radionuclides in Soil at the Shipoingoort Atomic Power Station Based on $10 \mathrm{mrem} / \mathrm{yr}$ to the Maximally-Exposed Individual 


\section{ACKNOWLEDGMENTS}

The authors would like to thank all of those individuals who helped make this study possible. In particular, we would like to thank Noma Van Houten for her efforts in preparing and correcting the manuscript. We would al so 1 ike to thank Ed Watson for offering ouidance, assistance, and encouragement in developing the methods and philosophy applied in this redort. 


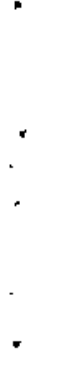




\subsection{INTRODUCTION}

The U.S. Department of Energy (DOE) is in the process of decommissioning the Shippingport Atomic Power Station. Because the reactor facility is owned by the DOE, it does not fall under the licensing authority of the U.S. Nuclear Regulatory Commission (NRC). This means that there are no NRC license termination requirements for decommissioning the Dower station. However, the DOE fully intends to comply with all local, state, and federal regulations that do apply. A major consideration in achieving an unrestricted release of the site after decommissioning is a determination of the amount (or level) of soil contamination that can be allowed to safely remain at the site. This report contains a description of a method for determining Allowable Residual Contamination Levels (ARCL) for radionuclides remaining in the soil at the Shippingport Atomic Power Station after decommissioning. This method is intended to be used with information from site surveys to determine the initial contamination level and to document that decontamination activities are completed.

The ARCL method is based on a scenario/exposure-dathway analysis and compliance with an annual dose limit for unrestricted use of the oroderty. A brief description of the Shippingport Atomic Power Station, current regulations regarding residual contamination, and the history of the development of the ARCL method is given in the remainder of this section. A more complete description of the ARCL method is given in Section 2. A description of the Shippingport Atomic Power Station is given in Section 3 and the actual ARCL calculations and results are given in Section 4. Finally, the results of the ARCL method are discussed in Section 5.

\subsection{THE SHIPPINGPORT ATOMIC POWER STATION}

The Shippingport Atomic Power Station is located on the south bank of the Ohio River in the borough of Shippingport, Pennsylvania. Shippingport is located in Beaver County hordering the state of Ohio and West Virginia. The power station is located on a 490-acre tract of land owned by the Duquesne Light Company. This site also serves as the site for the Beaver 


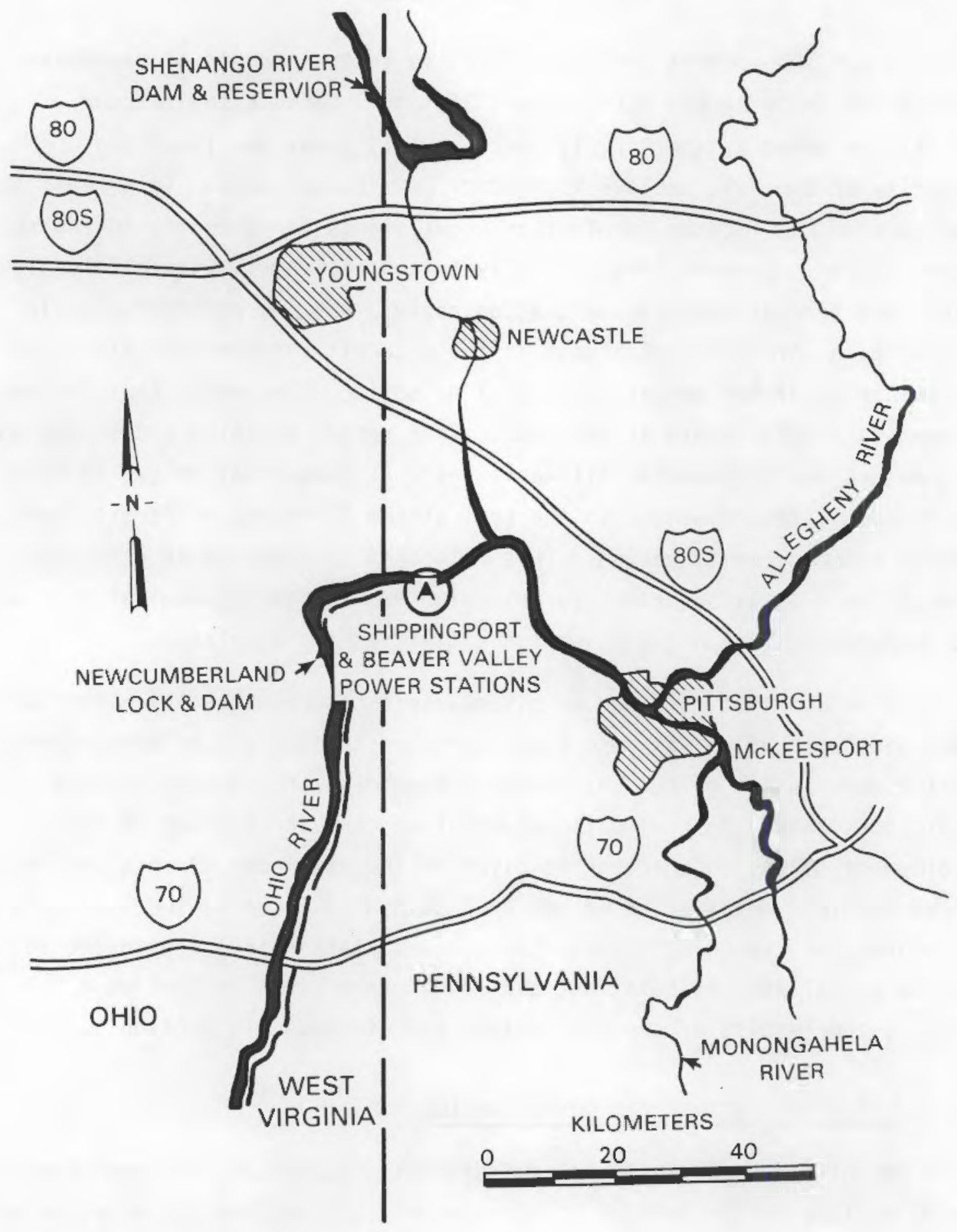

FIGURE 1.1.1. Map Showing the Shippingport Site 
Valley Nuclear Power Station (see Figure 1.1.1). The Atomic Energy Commission (AEC) leased six acres of land from Duquesne Light in 1954 on which to build a Dortion of the Shippingoort Atomic Power Station (U.S. DOE 1982). The present lease includes a total of seven acres and upon termination it requires the DOE to "make the premises safe from a radiation standooint" prior to transfer of ownership to Duquesne Light.

The Shippingport Atomic Power Station was constructed in the mid1950 's as a joint project of the U.S. Government and the Duquesne Light Company. The nuclear reactor is owned by the DOE and the turbine generator is owned by Duquesne Light. The nuclear reactor began operation in 1957 under supervision of the Naval Reactors Division of the DOE. The primary purpose of the reactor was to provide a means for investigating the technical, practical, and evolutionary considerations of commercial electrical energy production. During its operation, the reactor had two different water-cooled, seed-blanket PWR core designs and one light-water breeder reactor (LWBR) core design. The first PWR core began operation in 1957 with an electrical output of 68 MWe gross. In 1964, after modifications, the second PWR core began oderation with an electrical output of 150 MWe gross. The LWBR core was designed to produce $233 \mathrm{U}$ from $232 \mathrm{Th}$, and had an electrical output of 72 MWe gross (1).S. DOE 1982). Further details about the Shippingport Atomic Power Station are given in Section 3.

\subsection{EXISTING DECOMMISSIONIMG STANDARDS}

An examination of existing guidelines and regulations shows that there is a need for a general method of deriving allowable levels of radioactive contamination to permit release of decommissioned nuclear facilities. Currently, there is guidance provided by the U.S. Nuclear Regulatory Commission (NRC) for termination of commercial reactor licenses in Regulatory Guide 1.86 (U.S. AEC 1974), and for release of decontaminated facilities and equipment from by-product, source, or special nuclear material manufacture (U.S. NRC 1976). Other criteria for operation and/or decommissioning of nuclear facilities have been adopted by the NRC (Federal 
Register 1981), and the U.S. Environmental Protection Agency (40 CFR 190; 40 CFR 192; Federal Register 1983).

In addition, numerous criteria and standards have been developed for soil contamination. In a recent review of such guidance, Mueller, Kennedy, and Soldat (1981) concluded that it was difficult to compare soil standards since each was intended for a different situation, and since different units or bases were used. However, most of the soil contamination information reviewed was consistent with the philosophy of maintaining exposures at levels "as low as reasonably achievable" (ALARA). In general, it is difficult to compare the decontamination 1 imits given in most of the cited standards since each was intended for a specific situation and mixture of radionuclides, and since different units are used. Some of the limits specify radionuclide concentrations, while others specify an allowable dose or dose rate.

Methods have been oroposed by Healy (1974; 1979), Pacific Northwest Laboratory (Kennedy et al. 1979; Napier 1982), and Oak Ridge Nationa? Laboratory (Eckeman and Young 1980) that define techniques for calculating dllowable residual contamination levels for any mixture of radionuclides. These methods all rely on a scenario/exposure-pathway analysis based on an acceotable annual dose. The ARCL method applied in this report is such a method.

\subsection{HISTORY OF THE ALLOWABLE RESIDUAL CONTAMINATION LEVEL METHOD}

The ARCL method has been under development at Pacific Northwest Laboratory since 1976. Its first application was as part of a concentua? decommissioning study conducted for the NRC (Schneider and Jenkins 1977). The method has continued to evolve as the NRC conceptual decommissioning studies considered a variety of nuclear facilities ranging from fue 1 fabrication through reactor operation to low-level waste disposal and independent spent fuel storage. Example applications of the ARCL method to reactors that directly relate to this study are contained in reports by Smith, Konzek, and Kennedy (1978), Oak et al. (1980), and Konzek et al. (1982). 
In a recent journal article by Kennedy, Napier, and Soldat (1983) and in a document by Napier (1982), the ARCL method is formally described and the results of example calculations are presentad. In addition, Napier (1982) presented a comparison of ARCL results with other recommendations. In a related application, kennedy et al. (1982) investigated transuranic advanced-disposal systems and applied the ARCL method to develop preliminary 239Pu waste-disposal criteria for the Hanford Site. These criteria related depth of disposal to allowable concentration based on human intrusion scenarios.

The radiation-exposure scenarios described and used in this report are similar to those used by the NRC to develop criteria for shallow-land buria) grounds (U.S. NRC 1982). The major differences are in how the results of the two studies are intended to be used. The NRC provided a "generic" classification system for low-level radioactive waste disposal, while the results contained in this report are designed to define unrestricted use soil contamination levels that rely on site-specific conditions. Mo attempt has been made in this study to convert ARCL soil contamination values to readings on Dortable, field radiation survey instruments. Such conversion is beyond the intent of this reoort. The exact conversion factors will be highly dependent on the radionuclides present, their distribution wi th depth in the soil, and the particular instruments used. Calibration of the instruments is best accomplished by comparing actual field measurements with the results of laboratory analysis of soil samples. 


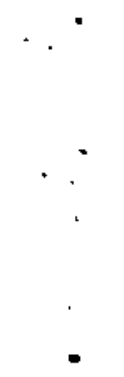


2.0 THE ALLOWABLE RESIDUAL CONTAMINATION LEVEL METHOD

The objective of the analysis of the Allowable Residual Contamination Levels (ARCL) of radionuclides in soil at the Shippingport Atomic Power Station is the determination of whether radioactively-contaminated soil areas require further decontamination or remedial action orior to release. The results of the analysis, when compared with radiation survey data, also indicate the general magnitude of remedial actions required orior to the release. The basic approach taken to calculate the ARCL is presented in this section.

In general, the ARCL values derived for radionuclides in soil are dependent on the physical characteristics of each individual contaminated site (size, radionuclide inventory, presence of structures), on the radiation dose 1 imit determined to be "acceptahle", and on the scenarios of human exoosure judged both to be possible and to result in upper bounds of exposure. The physical characteristics can be determined from a comprehensive site description. Dose limits for decommissioning have not yet been set by regulatory agencies. The draft generic environmental impact statement on decommissioning nuclear facilities (U.S. NRC 1981) contains a recommendation that the allowable residual radioactivity level for facility release be based on the dose anticipated to be received by individuals who use that facility. As set forth in the Energy Reorganization Act of 1974, the EPA has responsibility for establishina radiation dose standards for the protection of public health and safety. EPA has not yet instituted these criteria and is not scheduled to do so until 1984 (U.S. NRC 1981). For this report, unrestricted use of the site is assumed to occur immediately after decommissioning tasks are combleted. The ARCL calculations in this report are based on an assumed dose limit of $10 \mathrm{mrem} / \mathrm{yr}$; however, campliance with any other dose limit can be determined using the methods described in the worksheet provided in section 4.0 . The depth of clean overburden above the contaminated soil can affect the mechanisms by which the radionuclides are transported into the human exposure pathways. In this report, separate scenarios are formulated and separate ARCL values are generated for two cases: contamination located in the 
upper meter of soil, and contamination covered by a layer of clean soil 1-4 m thick.

\subsection{SUMMARY OF THE METHOO}

A simplified logic diagram of the ARCL method is shown in Figure 2.1.1. As illustrated, the necessary prerequisite to any analysis is characterization of the contaminated area, including location, size, radionuclide inventory, depth of overburden (for contaminated soil zones), and descriptions of existing barriers to waste migration and to human intrusion. These details, in conjunction with a description of the proposed release mode, allow preparation of realistic site-specific radiation-exposure scenarios. The heart of the ARCL method is an analysis of the maximum annual radiation dose to an exposed individual. If the dose potential to the individual is less than the design objective dose limit (assumed to be $10 \mathrm{mrem} / \mathrm{yr}$ for this analysis), then no further cleanup actions are

required. If it is predicted that the ootential dose may exceed the desian objective, further decontamination is indicated.

The general method for calculating the ARCL of radionuclides in soil consists of four steps:

1. From the information presented in the site descriotion, develoo a plausible scenario (or set of scenarios) for transfer of contamination to an individual consistent. with the proposed future use of the land.

2. From the radionuclide inventory given in the site descrintion, calculate the maximum annual radiation dose for the future-use mode exposure scenario for the site.

3. Calculate the ARCL for all nuclides in the mixture, back calculating from the maximum annual dose. This calculation is performed for those times that may maximize the potential dose.

4. Test whether apolication of additional engineered barriers or removal of certain areas of contamination will improve the site 


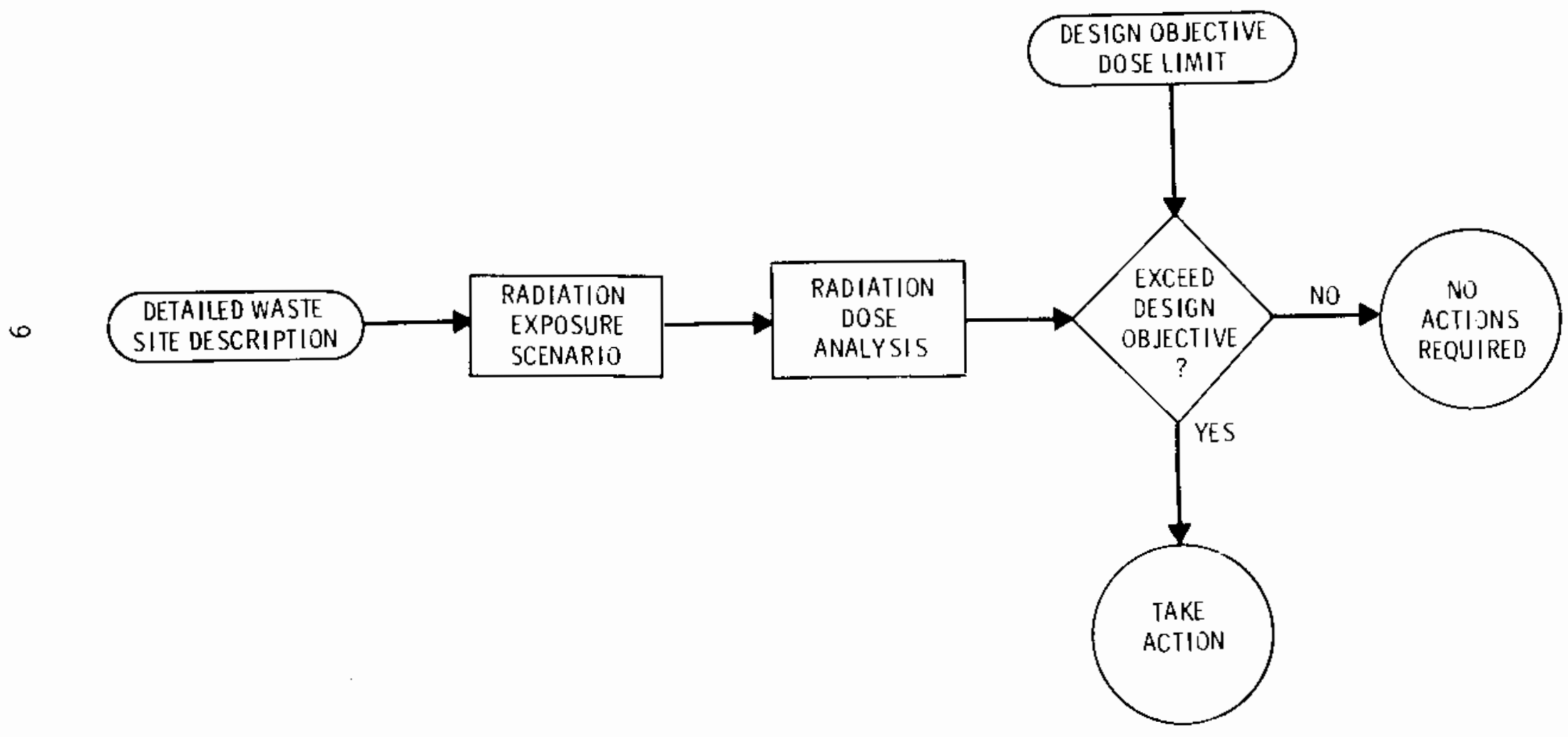

FIGURE 2.1.1. Allowable Residual Contamination Level Method Loqic Diagram 
characteristics. Note: This test depends upon condition-specific information and is not demonstrated in this report.

The primary objective of the ARCL is to determine whether or not an individual facility or site requires further decontamination or remedial actions prior to release. A secondary objective is to determine what remedial actions could be effective. The ARCL method does not choose the most appropriate disposal al ternative, nor does it automatically identify the best means of hazard mitigation. Analysis of remedial actions is simply an extended analysis of a site with modified physical characteristics to cause an impact on the exposure scenarios considered.

\subsection{ALLOWABLE RESIDUAL CONTAMINATION LEVELS}

The design objective is a limit on the maximum annual radiation dose to an individuat. The annual dose is a function of the auantity and spectrum of contaminant radionuclides and the exposure pathways to man. The desianobjective dose limit is converted to the site-specific, measurable quantity (the ARCL, in DCi/gram for soils) through applicable exposure scenarios. Each of these concepts is described in this section.

\subsubsection{Maximum Annual Dose}

There are four basic categories of public radiation doses that could be calculated to measure public exposure. These are:

1. One-year Dose. This is the dose from one year of exposure (externat plus internal). The one-year dose is currently used for comoarison with occupational exposure standards and the one originally used for comparison with public standards.

2. Committed Dose. This is the dose from one-year external exposure plus extended internal dose accumulated as a result of a one-year intake (ingestion plus inhalation). Nomally, a 50- or 70-year dose commitment period is used. The committed dose is the one currently being used by most of those who calculate public doses, and is the one used for occupational exposures in 10 CFR 20 (1982). 
3. Accumulated Dose. This is the dose from a 1 ifetime (50 or 70 years) of external exposure plus intake via ingestion and inhalation. This includes the effects of radionuclide accumulation or decay in the environment during the exposure period. The accumulated dose can be most closely related to health effects resulting from radiation exposure.

4. Maximum Annual Dose. This is the dose during a lifetime (50 or 70 years), and is calculated for each year of exposure accounting for each year's external exposure olus the internal dose from radionuclides taken in during the year of interest and all previous years. The maximum annual dose is identified by inspection for each oraan. This type corresponds most closely to the existing guides for occupational and public exposure which coitain standards for annual radiation dose.

The method for determining ARCL used in this report is a comparison of a calculated maximum annual dose received by a maximally-exposed individual wi th annual dose limits (Kennedy, Napier, and Soldat 1983). When internal exposure from $i$ nhalation and/or ingestion is the dominant dose contributor during continuous exposure, the maximum annual dose may not occur in the first year. Thus, for continuous exposure a first-year dose may not predict the most restrictive contamination level. Alternative methods might include calculation of the dose commitment from one year of exposure or calculation of the lifetime integrated dose from continuous exposure; however, no recognized standards limiting these types of doses exist. Thus, the maximum annual dose is most appropriate and is used in determining ARCL values for the Shippingport site.

\subsubsection{Radiation Exposure Pathways and Exposure Scenarios}

The potential routes through which people may be exposed to radionuclides or radiation are called "exposure pathways". The general pathways can be thought of as external exposure, inhalation, and ingestion. External exposure results from direct radiation from air, water, soil, and contaminated structures. Doses from inhalation can result from breathing 
aerosols released from facilities or from resuspended materials. Ingestion Dathways are water, fish, waterfow1, game, food crops, animal products, or direct consumption of small amounts of material transferred from surfaces to the hands. The ARCL for individual sites is based on the sum of exposures through all the selected pathways in a radiation exposure scenario analysis.

The key to the ARCL method, as shown in Fiqure 2.1 .1 , is an analysis of the maximum annual radiation dose to an individual. This dose is calculated by summing the doses from many exposure bathways. The pathways are chosen depending on the ways an individual could be exposed for the use mode considered. The collection of appronriate pathways is called an "exposure scenario". The flexibility to choose the exposure scenario enables the ARCL method to handle many types of sites, inventories, and locations.

In general, for all times and for all exposure scenarios, radiation dose rates to the individuals living out of the immediate vicinity of contaminated areas have been shown to be orders of magnitude smaller than those received by the onsite individual (Kennedy, Napier, and Soldat 1983). Thus, the onsite exposure scenarios have been determined to be the most critical. For unrestricted use, the general types of potential exposure scenarios for the maximally-exposed individual are as follows:

- transient or inadvertent intruder

- nemanent resident

- well drilling, excavation

- contact with soil, inhalation of resuspended material

- drinking of well water

- backyard garden

- intentional intruder

- resource recovery

- recovered resource use. 
The potential for radiation doses to individuals have been examined for each of these general scenarios. The most restrictive are examined in detail in this report. For contaminated soil areas, the permanent resident is the individual most likely to receive the largest radiation doses. Transients receive lesser exposure and there is little of value in the contaminated soil to entice the intentional intruder.

For unrestricted use of the site, the maximally-exposed individual is assumed to be exposed as a result of two scenarios. These scenarios are designed to consider residential/home-garden and residential/construction activities. The residential/home-garden scenario is designed to be similar to the scenarios considered by the NRC in the Draft Environmental Impact Statement in support of 10 CFR Part 61. The major differences are that the ARCL values calculated for unrestricted use in this report are based on an as sumed allowable organ dose of $10 \mathrm{mrem} / \mathrm{yr}$ instead of $500 \mathrm{mrem} / \mathrm{yr}$ and model soil contamination instead of low-level radioactive waste. More detail on these two exposure scenarios is given in Section 4. 
. 


\subsection{FACILITY DESCP.IPTION}

As background for the analysis of Allowable Residual Contamination Levels (ARCL) for soil contamination at the Shippingport Atomic Power Station site, we have developed brief discussions of the physical and radiological characteristics of the facility and site. The purpose of this section is to provide this background information. More detailed information about the facility, its operation and current decommissioning plans can be found in documents by the U.S. Energy Research \& Development Administration (U.S. EROA 1976) and the U.S. Department of Energy (U.S. DOE 1982).

\subsection{THE SHIPPINGPORT ATOMIC POWER STATION}

The Shippingnort Atonic Power Station is located on the south bank of the Ohio River about $40 \mathrm{~km}$ northwest of Pittsburgh, Pennsylvania (Logsdon and Chissler 1970). It is located in the borough of Shippingport in Beaver County which borders the states of onio and west Virginia. The power station was initially designed to use a préssurized-water nuclear reactor of Westinghouse design and was the first large-scale central station application for the civilian generation of nuclear power (U.S. ERDA 1976). The power station was constructed in the mid-1950's as a joint project of the U.S. Governent and the Duquesne Light Company. The nuclear reactor and associated buildings are owmed by the DOE and the turbine generator is owned by Duquesne Light Company. Reactor operations began at the site in December, 1957 and continued until 0ctober, 1982 using three different core designs. The first two cores were of PWR design and the last was of a light-water breeder reactor (LWBR) design. The first PWR core operated from 1957 to early 1964 with a gross electrical power rating of 68 Mile and included three partial refuelings. The second PWR core oderated from early 1965 to early 1977 with a gross electrical Dower rating of 150 MWe and included one refueling (U.S. DOE 1982). Finally, the LWBR core operated from mid-1977 until late 1982 with a gross electrical power rating of 72

MWe. The LWBR core was designed to produce $233 \mathrm{U}$ from 232 Th and it was intended to develop and demonstrate basic LWBR design technology (U.S. ERDA 1976). 
The DOE currently leases the seven-acre Shippingport reactor site from the Duquesne Liqht Company. This site is adjacent to a larger (490-acre) Duquesne Light Company site on which the Beaver valley Uuclear Power Station was constructed. A detailed site plan for the Shippingport Atomic Power station is shown in Figure 3.1.1 (U.S. DOE 1982). The two boiler chambers are located on either side of the reactor building as shown in the figure. In addition to the reactor and turbine buildings, several other ancillary structures are present on the site. Some of these structures include: the radioactive waste processing building, the contaminated equipment room, the test/training building, and the intake and discharge structures (U.S. DOE 1982).

\subsection{RADIONUCLIDE INVENTORY}

The ARCL values for soil at the Shippingport Atomic Power Station will be dependent upon the mixture of radionuclides present after decnmissioning has been completed. This mixture will best be determined as part of the post-decammissioning survey. Adart from naturally occurring radionuclides and fallout from woons testing, radionuclide soil contamination could potentially come from five sources. They are: operation of the Shippingport reactor as a PWR, operation of the Shiopingport reactor as an LWBR, operation of the nearby Beaver Valley reactors, releases during decommissioning activities, and operation of nearby industries, including the Bruce Mansfield coal-fired power plant. The pre-operational soil contamination characteristics are not known and an examination of annual environmental reports for the Shippingport power station since 1959 revealed little information that was useful for estimating the accumulation of radionuclides in soil onsite (U.S. DHEW 1960-1965; U.S. DHEW 1966-1971; U.S. EPA 1972-1974; Duquesne Light Company 1972, 1974-1979 and 1982; Logsdon and Chissler 1970). In addition, the soil contamination levels may change as a result of future decommissioning operations and the continued operation of the Beaver Valley Nuclear Station. Thus, it is not feasible at this time to quantify the exact level of soil contamination expected at the end of decommissioning activities. Therefore, we have developed a list of radionuclides that are potentially important contributors to dose. The 


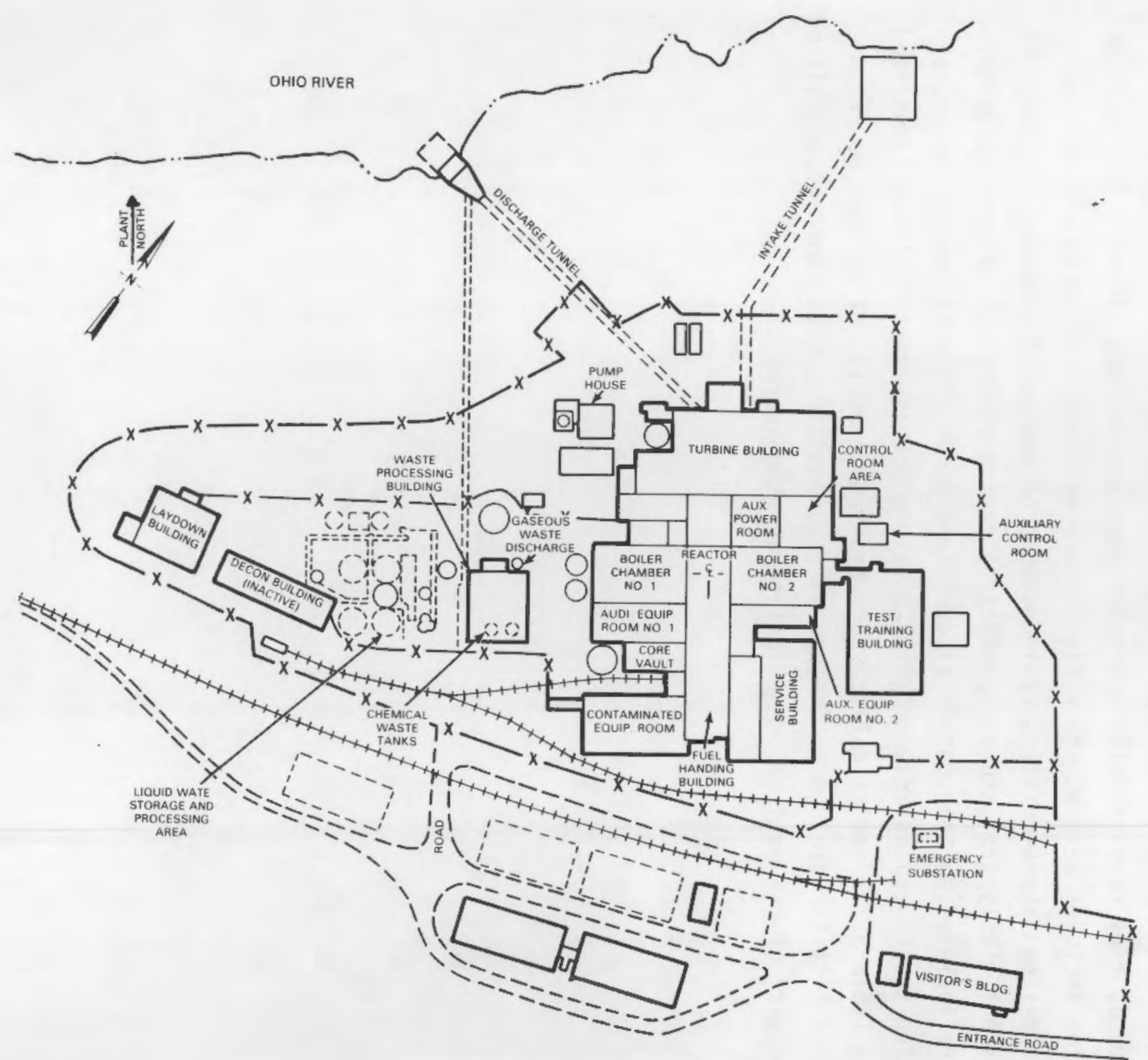

FIGURE 3.1.1. Shippingport Station Site Plan 
list is shown in Table 3.2.1. Radionuclides are included if: 1) they are identified in the annual reports for PWR or LWBR operations at Shippingport, 2) they are identified in a previous review of gaseous effluent releases for operating PWR's (Smith et al. 1978, Section 7.3.2), and 3) they have half-lives greater than six months. In addition, we have also included several other fission and activation products and several long-lived alpha-emitting radionuclides of potential concern. Although it is not likely that the alpha-emitting radionuclides will be present, they are included so that potential questions about their allowable contamination levels can be answered. ARCL values for the radionuclides identified in Table 3.2.1 are calculated and reported in Section 4 of this report. This list is intended to include all radionuclides that could be identified as part of the post-decommissioning radiation survey. 


\section{TABLE 3.2.1. Potential Radionuclides Accumulated}

on the Shippingport Site

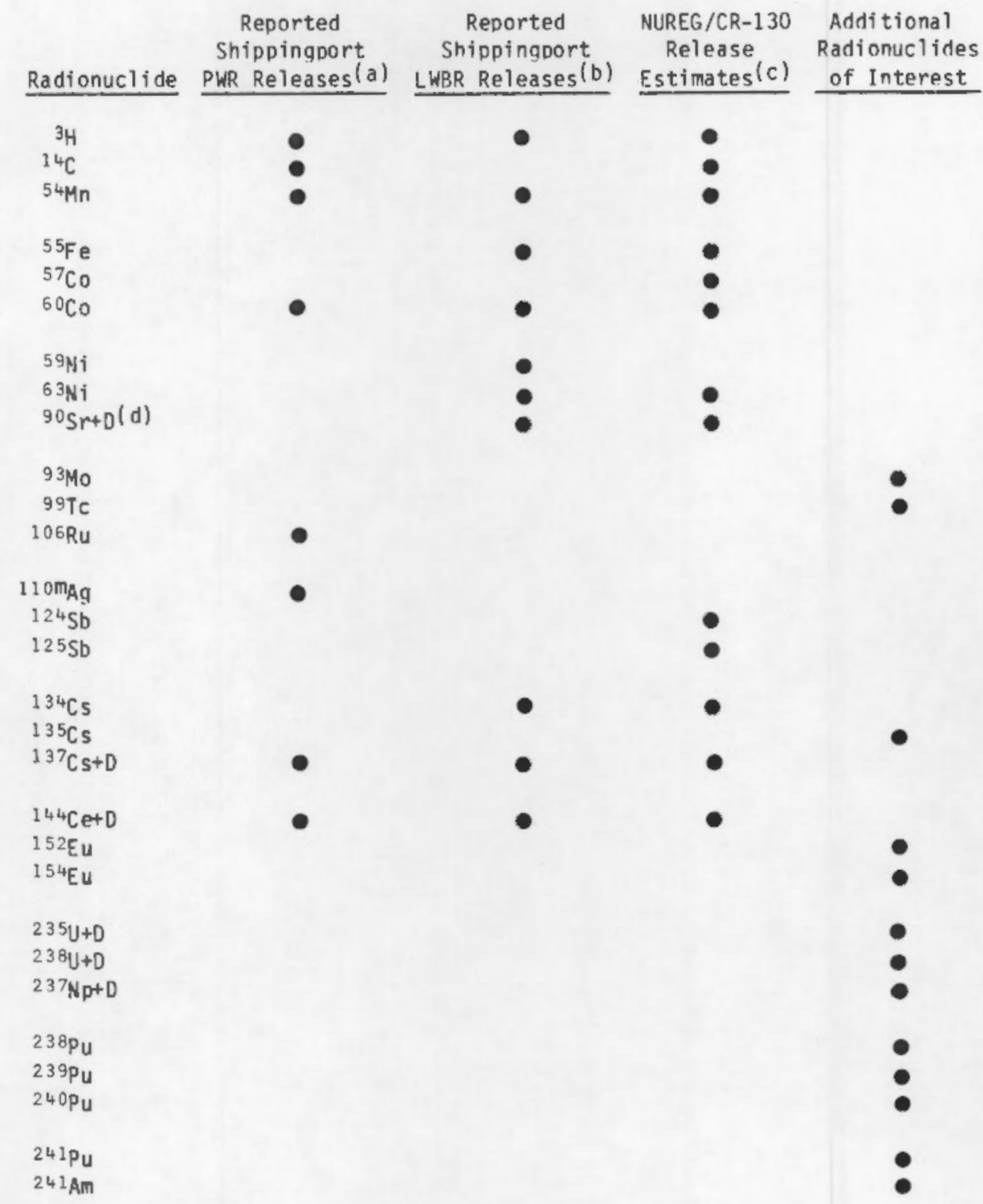

(a) Based on information from Radiological Health Data (1960-1965); Radiological Health Data and Reports (1966-1972), Radiation Data and Reports (1972-1974), Duquesne Light Company (1972, 1974-1978), and Logsdon and Chissler (1970).

(b) Based on information from U.S. ERDA (1976) and Duquesne Light Company (1979, 1982).

(c) Based on information from Smith et al. (1978).

(d) $+D$ means plus short-lived daughters. 



\subsection{ALLOWABLE RESIDUAL CONTAMINATION LEVEL CALCULATIONS}

The step-by-step procedure for calculating Allowable Residual Contamination Levels (ARCL) for soil contamination at the Shippingport Atomic Power Station is outlined in this section. After a brief description of the radiation exposure scenarios, the dose models used for assessing exposures by various pathways are described and ARCL maximum organ dose-conversion factors are developed for a set. of 29 radionuclides of potential interest after decomissioning. ARCL values for individual radionuclides are next developed. Finality, a procedure is described to permit consideration of any mixture of the 29 radionuclides at any time of interest. This procedure will permit final certification of the site to unrestricted-use contamination levels based on information from the post-decommissioning survey.

\subsection{RADIATION EXPOSURE SCENARIOS}

For unrestricted use, the allowable residual contamination levels for each radionuclide are determined using the results of two exposure scenarios. These scenarios are the residential/home-garden scenario and the residential/construction scenario, chosen in Section 2.2.2. Both unconfined (surface) and confined (subsurface) soil contamination conditions are considered. These calculations are intended to represent general soil conditions after decommissioning and any soil contamination left intentionally under a clean soil layer. The following sections contain discussions of the two unrestricted-use scenarios considered in this study.

\subsubsection{Residential/Home-Garden Scenario}

This scenario is designed to represent the unrestricted-use exposure conditions of an individual who resides on the site and engages in home gardening activities for 50 years. For this scenario, the individual is assumed to spend 12 hours per day outdoors on the site, during which he is exposed to direct penetrating radiation from the soit. The individual is al so as sumed to inhale resuscended contamination in the surface soil (if present.) for 12 hours per day during his 50 years of exposure. The air concentrations are calculated using a time-dependent resuspension factor to 
account for the environmental "aging" of radionuclides. This relationship is given as (Anspaugh et a1. 1975):

$$
S_{f}=\left(10^{-4} e^{-\lambda \sqrt{t}}\right)+10^{-9}
$$

where $S_{f}$ - resuspension factor, $\mathbb{m}^{-1}$

$$
\begin{aligned}
10^{-4} \text { - } & \text { resuspension factor at time } t=0, \mathrm{~m}^{-1} \\
\text { - effective decay constant controlling the availability of } & \text { material for resuspension, } 0.15 \text { day-1/2 } \\
\mathrm{t} \text { - } & \text { time after deposition, days } \\
10^{-9} \text { - } & \text { resuspension factor after } 17 \text { years, } \mathrm{m}^{-1}
\end{aligned}
$$

Finally, the individual is assumed to grow $50 \%$ of his fruit and veqetable diet in a backyard home garden located in the contaminated soil.

Unconfined soil contamination is assumed to be in the top meter of soil on the property, with no overburden layer. Home construction is not included in the residential/home-garden scenario because the individual does $m t$ have to dig to be exposed to contaminated soil and because dinaing may serv to dilute the surface contamination with clean soil. For confined soil, assuming an overturden layer of 1-4 m, a fraction of the buried contamination is assumed to be brought to the surface as a result of the residential/construction scenario (as discussed in the next section).

\subsubsection{Residential/Construction Scenario}

The residential/construction scenario is based on the intruderconstruction scenario developed by the U.S. Nuclear Regulatory Commission in the Draft Environmental Impact Statement in support of 10 CFR Part 61 (U.S. NRC 1981). For this scenario, an individual is assumed to dig a basement for a house into a subsurface radioactive soi) (or debris) zone. The radioactive soil is assumed to be between 1 and $4 \mathrm{~m}$ from the surface. Typical surface areas for a house are assumed to be $20 \mathrm{~m}$ by $10 \mathrm{~m}$, for an area of $200 \mathrm{~m}^{2}$. This dimension is assumed for the base of the foundation hole. The foundation hole is assumed to be $3.5 \mathrm{~m}$ deep, with surface dimensions of $26 \mathrm{~m}$ by $16 \mathrm{~m}$. The total excavation is assumed to involve 
about $200 \mathrm{~m}^{3}$ of contaminated soil mixed with $800 \mathrm{~m}^{3}$ of clean overburden soil. Thus, the resulting $1000 \mathrm{~m}^{3}$ mixture has a radionuclide concentration that is $20 \%$ of the original concentration of contaminated soil. The contaminated soil mixture is assumed to be used as fill around the house and distributed uniformly on the surface within a $25-m$ radius around the house.

For the residential/construction scenario, dose estimates are made for the individual both during and after the construction activities. The most. restrictive individual doses, resulting from both scenarios for each radionuclide, are then used in the ARCL calculation. During construction, the individual is assumed to spend 500 hours (over about a 3-month period) on the site. The individual is as sumed to inhale air with a dust concentration of $1 \times 10^{-4} \mathrm{~g} / \mathrm{m}^{3}$ and be exposed to direct radiation for the 500 -hour construction period. After the house is constructed, the individual is assumed to reside there and conduct activities similar to those identified by the NRC for the intruder/agriculture scenario. (U.S. NP.C 1981). These conditions are described in Section 4.1.1 for the residential/home-qarden scenario.

\subsection{DOSE MODELS FOR RADIATION EXPOSURE PATHWAYS}

The method for calculating ARCL values relies on an analysis of maximum annual radiation doses resulting from the limiting radiation exposure scenarios. For long-tem (or continuous) exposure during the unrestricted-use scenarios, the maximum dose to internal organs may not occur in the first year. This is because specific radionuclides may accumulate in internal organs as a function of their rate of intake and their physical and biological half-lives. The PNL computer program MAXI (Napier et a1. 1979; Murphy and Holter 1980) is used in this study to calculate maximum annual doses from continuous exposures. The MAXI program uses dose factors from DACRIN (Houston, Strenge, and watson 1976) for inhalation, and the FOOD and ARRRG computer programs (Napier et al. 1980) for ingestion of food products. The DACRIN computer program is hased on the Task Group on Lung Dynamics Mode1 (TGLM) (ICRP 1966). For this study, a particle size of $1 \mu m$ activity-median aerodynamic diameter (AMAD) is 
assumed. This particle size is within the respirable size distribution and is a "standard" assumption when detailed information on the particle size distribution is not available. To account for the retention of radionuclides in the lung, a translocation class of either Class $D$ (days) or $W$ (weeks) material is used for all internal organs except lung and G.I. tract (lower large intestine), where a classification of either $W$ or $Y$ (years) is assumed. These assumptions tend to maximize the specific internal organ doses obtained from the ICRP task group on lung dynamics model (TGLM) equations and are rather "standard" for situations where the exact chemical properties of radionuclides are not known. Further discussions of the mathematical model used in the MAXI computer program are given in documents by Kennedy et a 1. (1979), Murphy and Holter (1980), and Napier (1982).

\subsection{ALLOWABLE RESIDUAL CONTAMINATION LEVEL MAXIMUM ORGAN-DOSE CONVERSION FACTORS}

Maximum organ dose conversion factors, for determining ARCL values, are calculated by applying the exposure conditions defined in Section 4.1 for the radiation exposure scenarios, using the dose models previously discussed. The organs considered in the calculations are: total body, bone, lung, and G.I. tract (lower large intestine). ARCL dose conversion factors for soil contaminated with 29 individual radionuclides are shown in Table 4.3.1 for the unrestricted-use radiation exposure scenarios. The units of these dose factors are rem/yr per $\mathrm{pCi} / \mathrm{g}$ of soil. These dose factors are the largest (critical) organ dose resulting from exposure to each radionuclide for the scenarios considered. The factors are given for unconfined soil (in the top meter), and confined soil (at depths between 1-4 $\mathrm{m}$ from the surface). The dominant exposure pathway (i.e., direct, inhalation or ingestion) is also indicated for each radionuclide in Table 4.3 .1 . 
TABLE 4.3.1. Scenario-Specific Allowable Residual Contamination Level Dose Conversion Factors for the Shippingport Atomic Power Station

\begin{tabular}{|c|c|c|c|c|c|}
\hline \multirow[b]{2}{*}{ Radionuclide } & Column 1 & Column 2 & & & \multirow[b]{2}{*}{$\begin{array}{l}\text { Year of } \\
\text { Maximum } \\
\text { Annual } \\
\text { Dosele? } \\
\end{array}$} \\
\hline & $\begin{array}{c}\text { Unconfined Soil } \\
0-1 \mathrm{~m} \text { Deep } \\
\text { (Total rem/yr } \\
\text { per/oCi/g) }(\mathrm{b}) \\
\end{array}$ & $\begin{array}{l}\text { Confined Soil } \\
1-4 \mathrm{~m} \text { Deep } \\
\text { (Tota) rem/yr } \\
\text { per/pCi/g)(c) }\end{array}$ & $\begin{array}{c}\text { Critical } \\
\text { Organ } \\
\end{array}$ & $\begin{array}{r}\text { Critical } \\
\text { Pathway } d\} \\
\end{array}$ & \\
\hline${ }^{3} \mathrm{H}$ & 1. $.7 \mathrm{E}-10^{(f)}$ & $3.4 E-11$ & Total Rody & Inhale & 1 \\
\hline${ }^{14} \mathrm{C}$ & $8.3 E-8$ & $1.7 \mathrm{E}-8$ & Total Pory & Ingest & \\
\hline $54 \mathrm{Mn}$ & $1.7 E-3$ & $3.4 E-4$ & Total Body & Direct. & 1 \\
\hline $55 \mathrm{Fe}$ & $1.0 E-7$ & $2.0 E-8$ & Bone & Ingest & 4 \\
\hline${ }^{57} \mathrm{CO}$ & $2.3 E-7$ & $4.6 E-8$ & Total Body & Ingest. & 1 \\
\hline$\because C \mathrm{CO}$ & $1.1 E-2$ & $2.2 E-3$ & Total Body & Direct. & 1 \\
\hline $59 \mathrm{Ni}$ & $4.3 E-5$ & $8.6 \mathrm{E}-6$ & Bone & Ingest & 25 \\
\hline $5,7 \mathrm{Ni}$ & $5.2 \mathrm{E}-4$ & $1.0 E-4$ & Rone & Innesst. & 12 \\
\hline $90 \mathrm{Sr}+0(\mathrm{~g})$ & $1.1 \mathrm{E}-2$ & $2.2 E-3$ & Bone & Inqest. & 20 \\
\hline $93 \mathrm{Mo}$ & $6.0 E-6$ & $1.2 E-6$ & Total Body & Ingest & 2 \\
\hline $99 \mathrm{Tc}$ & $3.9 E-4$ & 7.8E -5 & G.I. Tract & Ingest & 1 \\
\hline $106: R u$ & $2.2 \mathrm{E}-4$ & $4.5 \mathrm{E}-5$ & G.I. Tract & Ingest. & 1 \\
\hline $110 \mathrm{mi} \mathrm{Ag}$ & $5.3 E-3$ & $1.0 \mathrm{E}-3$ & Total sody & Direct & 1 \\
\hline 12450 & $2.7 E-5$ & $5.4 E-6$ & Total Body & Direct & 1 \\
\hline $125 \mathrm{Sb}$ & $1.7 \mathrm{E}-3$ & $3.4 E-4$ & Total Body & Direct & 1 \\
\hline $134 \mathrm{Cs}$ & $5.7 \mathrm{E}-3$ & $1.1 E-3$ & Total Body & Direct & 1 \\
\hline $1.35 \mathrm{CS}$ & $9.0 \mathrm{E}-6$ & $1.8 \mathrm{E}-6$ & Bone & Ingest & 5 \\
\hline $137 \mathrm{Cs}+0$ & $2.7 \mathrm{E}-3$ & $5.3 E-4$ & Total Rody & Direct & 1 \\
\hline $144 \mathrm{Ce}+0$ & $1.3 E-5$ & $2.7 E-6$ & Total Sindy & Direct & 1 \\
\hline $152 \mathrm{Eu}$ & $5.0 \mathrm{E}-3$ & $1.0 E-3$ & Total Body & Direct. & 1 \\
\hline $154 \mathrm{Eu}$ & $5.4 \mathrm{E}-3$ & $1.1 E-3$ & Total Bory & Direct & 1 \\
\hline $23 \vdots u+0$ & $5.0 \mathrm{E}-4$ & $1.0 \mathrm{E}-4$ & G.I. Tract & Ingest & 1 \\
\hline $238 \mathrm{U}+0$ & $4.4 \mathrm{E}-4$ & B. $8 \mathrm{E}-5$ & Rone & Ingest & 50 \\
\hline $237 \mathrm{ND}+\mathrm{D}$ & $7.3 E-4$ & $1.5 F-4$ & Bone & Ingest. & 50 \\
\hline $235 \mathrm{Pu}$ & $6.2 E-5$ & $1.2 E-5$ & Bone & Inhale & 50 \\
\hline $239 \mathrm{Pu}$ & $8.8 \mathrm{E}-5$ & 1.RE -5 & Bone & Inhale & 50 \\
\hline $2143 \mathrm{Pu}$ & R. $8 \mathrm{E}-5$ & $1.8 \mathrm{E}-5$ & Bone & linale & 50 \\
\hline $2+1 \mathrm{Pu}$ & $3.6 \mathrm{E}-7$ & $7.2 \mathrm{E}-8$ & Bone & Inhale & 50 \\
\hline $241 \mathrm{Am}$ & $1.4 E-4$ & $2.8 E-5$ & 3one & Intale & 50 \\
\hline
\end{tabular}

(a) Based on $1 \mathrm{pCi} / \mathrm{g}$ of each radionuclide (or parent for to radionuclidest in surface or subsurface soils.

(b) For the residential/home-garden scenario.

(c) Based on the most restrictive of the residential/construction and the residential/home-garden scenarios.

(d) Where Direct means direct exposure, Ingest means ingestion and Inhale means inhalation.

(e) The year after the start of a 50-year continusous-exposure period in which the maximum annual dose occurs.

(f) where $1.7 E-10=1.7 \times 10^{-10}$.

(g) to means ol us short-lived daughters. 
The dose conversion factors in Table 4.3.1 are converted to an allowable contamination level by simply dividing the allowable dose limit (0.01 reml $/ \mathrm{yr}$ ) by the dose conversion factor (in rem). The resulting ARCL values are shown in Table 4.3.2. These values are the concentration levels (in $\mathrm{pCi} / \mathrm{g}$ of soil) of each individual (or parent radionuclide) radionuclide that would result in $0.01 \mathrm{rem} / \mathrm{yr}$ to the critical organ of an individual exposed during the two scenarios considered. In addition, the ARCL method permits consideration of various mixtures of radionuclides in the soil and alternatives to the assumed annual dose limit as discussed in the following section.

\subsection{ALLOWABLE RESIDUAL CONTAMINATION LEVEL WORKSHEET FOR RADIONUCLIDES IN THE SOIL AT THE SHIPPINGPORT ATOMIC POWER STATION}

The ARCL method permits the consideration of any combination of the 29 radionuclides shown in Table 4.3 .1 in soils at the Shippingport site. After decommissioning, the post-decommissioning survey will determine the actual contamination levels and mixtures present. By using the worksheet shown in Figure 4.4.1, a determination can be made of whether or not the contamination levels are less than the ARCL values for the mixture present. The following instructions explain how to use the worksheet.

1. Case Name. Enter the name or the numerical designation of the current case and other identification information.

2. Preparer's Hame. Enter the name of the oerson preparing the ARCL worksheet.

3. Date. Enter the date on which the worksheet was completed.

4. Determination of ARCL Dose Factors to Enter from Table 4.3.1. The calculation requires the proper dose factors, which are a function of the contamination condition. Check only one contamination condition to uniquely determine from the worksheet which column of Table 4.3.1 contains the proper factors. Factors are obtained from column 1 of Table 4.3.1 for unconfined (surface) soil, and from column 2 of Table 4.3.1 for confined (subsurface) soil. 
TARLE 4.3.2. Allowable Residual Contamination Level Values for Individual Radionuclides in Soil at the Shippingport Atomic Power Station Based on $10 \mathrm{mrem} / \mathrm{yr}$ to the Maximally-Exposed Individual

\begin{tabular}{|c|c|c|}
\hline Radionuclide & $\begin{array}{c}\text { Unconfined Soil } \\
0-1 \text { m Deep } \\
(n c i / g)(a)\end{array}$ & $\begin{array}{l}\text { Confined Soil } \\
1-4 \mathrm{~m} \text { Deep } \\
(\mathrm{nci} / \mathrm{a})(\mathrm{b})\end{array}$ \\
\hline${ }^{3} \mathrm{H}$ & $5.9 E+7(c)$ & $2.9 E+8$ \\
\hline $14 \mathrm{C}$ & 1. $2 \mathrm{E}+5$ & $5.9 E+5$ \\
\hline $53 M n$ & $5.9 E+0$ & $2.9 E+1$ \\
\hline $55 \mathrm{Fe}$ & $1.0 E+5$ & $5.0 E+5$ \\
\hline $57 \mathrm{Co}$ & $4.4 E+4$ & 2.?E+5 \\
\hline${ }^{60} \mathrm{CO}$ & $0.1 \mathrm{E}-1$ & $4.6 \mathrm{E}+0$ \\
\hline $59 \mathrm{Ni}$ & $2.3 E+2$ & $1.2 E+3$ \\
\hline $63 \mathrm{~N}$ & $1.9 E+1$ & 1. $.9 E+2$ \\
\hline $905 r+0(d)$ & $9.1 \mathrm{E}-1$ & $4.6 E+0$ \\
\hline $93 \% 10$ & $1.7 \mathrm{E}+3$ & R. $3 E+3$ \\
\hline $99 \mathrm{TC}$ & $2.6 E+1$ & $1.3 F+2$ \\
\hline$\because 0 \mathrm{Ru}$ & $4.6 E+1$ & $2.2 E+2$ \\
\hline $110 \mathrm{mAg}_{\mathrm{Ag}}$ & $1.9 E+0$ & 1. $.0 E+1$ \\
\hline $1245 b$ & $3.7 \mathrm{E}+2$ & $1.8 \mathrm{E}+3$ \\
\hline $125 \mathrm{Sb}$ & $5.9 E+0$ & $2.9 E+1$ \\
\hline $134 \mathrm{Cs}$ & $1.8 E+0$ & $9.1 E+0$ \\
\hline $135 \mathrm{cs}$ & $1.1 E+3$ & $5.6 E+3$ \\
\hline $137 C_{5}+D$ & $3.7 E+0$ & $1.9 \mathrm{E}+1$ \\
\hline $144 \mathrm{Ce}+0$ & $7.7 E+2$ & $3.7 E+3$ \\
\hline $152 \mathrm{Eu}$ & $2.0 E+0$ & $1.0 E+1$ \\
\hline $154 \mathrm{Eu}$ & $1.8 \mathrm{E}+0$ & $9.1 E+0$ \\
\hline $235 v+D$ & $2.0 E+1$ & $1.0 \mathrm{E}+2$ \\
\hline $238 \mathrm{U}+0$ & $2.3 E+1$ & $1.1 F+2$ \\
\hline $237 \mathrm{~Np}+0$ & $1.4 E+1$ & $6.7 \mathrm{E}+1$ \\
\hline $238 \mathrm{pu}$ & $1.6 E+2$ & 8. $3 \mathrm{E}+2$ \\
\hline $239 \mathrm{Pu}$ & $1.1 E+2$ & $5.6 E+2$ \\
\hline $240 \mathrm{pu}$ & $1.1 E+2$ & $5.6 \mathrm{E}+2$ \\
\hline $241 \mathrm{pu}$ & $2.8 E+4$ & 1. $4 E+5$ \\
\hline $241 \mathrm{Am}$ & $7,1 \mathrm{E}+1$ & $3.6 E+2$ \\
\hline
\end{tabular}

(a) Based on the residential/home-garden scenario.

(b) Based on the most restrictive of the residential/ construction and the residentia//home-garden scenarios.

(c) Where $5.9 \mathrm{E}+7=5.9 \times 10^{7}$.

(d) tD means plus short-lived daughters. 

1. Case Name:
2. Preparer's Name:
3. Date Preparad:

4. Determination of ARCL Dose Factors to Enter From Table 4.3.1. (Check Nne)

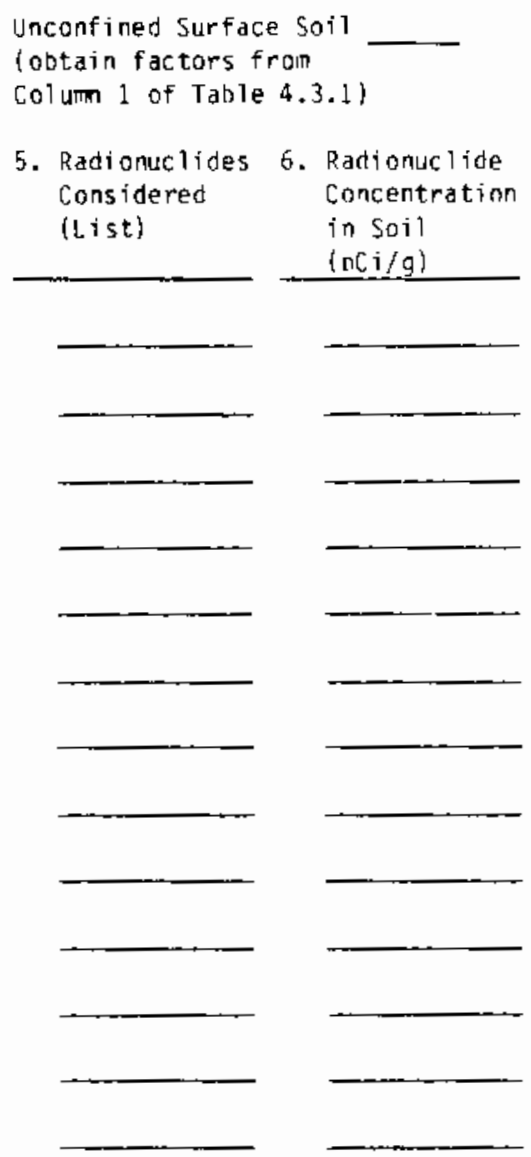

6ia. Total
Confined Subsurface Soil
Cobtain factors from
Column 2 of Table 4.3 .1 )

7. Scenario-5pecific ARCL Dose Factors

(From I tem 4: rem/yr ner $p[i / q]$

8. Prnduct of Itens $6 \& 7$ ( $\mathrm{rem} / \mathrm{yr}$ ) $\longrightarrow$
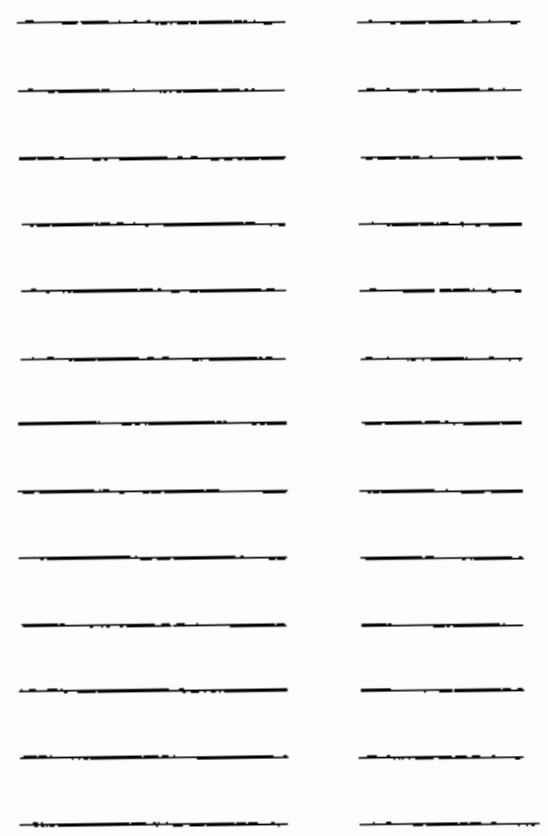

8a. Total

8b. $(0.01 \overline{\mathrm{ram} / \mathrm{Yr} / 8 \mathrm{a})}$

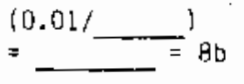

9. ARCL - oroduct

Item 6 and

Iteen $8 \mathrm{~b}$

(bci/a)
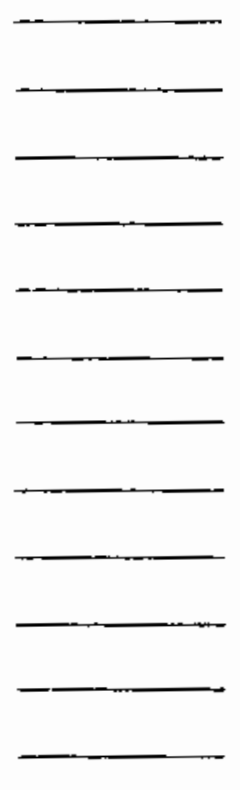

9. Tntal

9b. Check:

Does $8 \mathrm{~h}=9 \mathrm{a} / 6 \mathrm{a}$ ?

10. Present Gross Contamination Level Yielding Future ARCL of Item 9a: (llse only with Decay Correction Work sheet.) (9a) $\times$ (9 of Figure 4.4 .4 ) $=$

11. Additional Notes:

FIGURE 4.4.1. Allowable Residual Contamination Level Worksheet for Soil Contamination at the Shippingport Atomic Power Station Site 
5. Radionuclides Considered. Enter the radionuclides considered in the soace provided. If additional space is required, use additional worksheets.

6. Radionuclide Concentrations. The calculation reguires that the snurce inventory be given in terms of $\mathrm{pCi} / \mathrm{g}$ of soil. Total the results and enter in Item $6 \mathrm{a}$. The inventory may be given in either relative or absolute amounts.

7. Scenario-Specific ARCL Dose Factors. Enter the values from the approoriate column of Table 4.3.1 (as determined in Item 4) in units of rem/yr per $\mathrm{DCi} / \mathrm{g}$ for soils.

8. Product of Items 6 and 7 . Multiply the concentration of each radionuclide listed in Item 6 of the worksheet by its corresponding scenario-specific ARCL dose factor from Item 7 and enter in units of reri/yr. Sum all radionuclides and enter the total as Item $8 \mathrm{a}$. Next, divide the annual dose limit $(0.01 \mathrm{rem} / \mathrm{vr})$ by the total and enter the result as Item 8 b. Note: A different dose limit may be substituted in this step if desired.

9. ARCL. Multioly the concentration of each radionuclide listed in Item 6 of the worksheet by the correction factor of Item $8 \mathrm{~b}$ and enter the corresoonding ARCL values for each radinnuclide of the specific mixture in Item 9 in units of $\mathrm{pCi} / \mathrm{g}$. Sum all entries in Item 9 and enter the total mixture ARCL as Item 9a. The value calculated as Item $9 \mathrm{a}$ is the current total gross activity level that may be allowed to remain without exceeding the desired dose limit. At this point, a convenient mathenatical check may be made by dividing Item 9 a by Item $6 \mathrm{a}$; the result should be equal to Item $8 \mathrm{~b}$.

10. Optional Decay-Time Correction. If the radionuclide concentrations used in Item 6 were taken from the Radioactive Decay Correction Work sheet (Fiqure 4.4.4), then the result calculated as Item 9 a of the ARCL Worksheet (Fiqure 4.4.1) is the ARCL applicable to that future time. That is, it is the amount that may remain on the surface or in the soil at the future time of unrestricted release. To determine the 
present contamination level of the nuclide mixture that will result in the limiting dose at the future time, one additional step is necessary. Multiply the value of Item 9 a by the value of Item 9 from the Decay-Time Correction Work sheet.

11. Additional Notes. Add any additional comments or clarifications on the worksheet.

As an example of the use of the ARCL worksheet, two sample problems are next described. Both rely on a radionuclide mixture composed of $55 \mathrm{Fe}$ $(10 \%), 60 \mathrm{Co}(25 \%), 63 \mathrm{Ni}(15 \%), 90 \mathrm{~S} r+\mathrm{D}$ (0.05\%), 137Cs+D (20\%), 152Eu (15\%), and 154Eu (10\%) by activity. The first example problem considers surface soil contamination and the completed worksheet. is shown in fiqure 4.4.2. The radionuclides and relative concentrations are shown in Items 5 and 6 of the worksheet, with the total of $1 \mathrm{pCi} / \mathrm{g}$ reported in Item $6 \mathrm{a}$. Scenariospecific ARCL dose conversion factors are obtained from Table 4.3.1 (as shown by Item $A$ of the worksheet) and entered in Item 7. The nroduct of the entries in Items 6 and 7 of the worksheet aro entered as Item 8 . The total of Item 8 is entered as Item 8 a $(5.1 \mathrm{E}-3 \mathrm{rem} / \mathrm{yr})$. This is the cose in rem that an individual could receive as a result of exnosure (to a total soil concentration of $1 \mathrm{pCi} / \mathrm{g}$ ) during the residential/home-garden scenario. The ratio of the unrestricted use annual dose limit $(0.01$ rem) to the tota? in Item $8 \mathrm{a}$ is given in Item $8 \mathrm{~b}$, as 2.0 . This value, multiplied by the entries in Item 6 of the worksheet, results in the ARCL values for the specific radionuclides in the mixture. The sum of the individual radionuclide ARCL values is reported as $2.0 \mathrm{pCi} / \mathrm{g}$ in Item $9 \mathrm{a}$. The mathematical check of Item $9 b$ indicates that no non-compensating errors were propagated in the example calculation.

The second example problem consifers the same radionuclides and concentrations as in Example Problem 1, but for confined soil areas, with overburden depths of from 1-4 m. The completed worksheet for this examile problem is given in Figure 4.4.3. The scenario-specific ARCL dose conversion factors for this sample problem are obtained from Column 2 of Table 4.3.1 (as shown by Item 4 of the worksheet) and entered in Item 7. The product of the entries in Items 6 and 7 are entered in Item 8 . The 
1. Case name: Example Problem 1

2. Preparer's Name: W. E. KENNEDY, JR.

3. Date Prepared: $9 / 27 / 83$

4. Determination of ARCL Dose Factors to Enter From Table 4.3.1. (Check One)

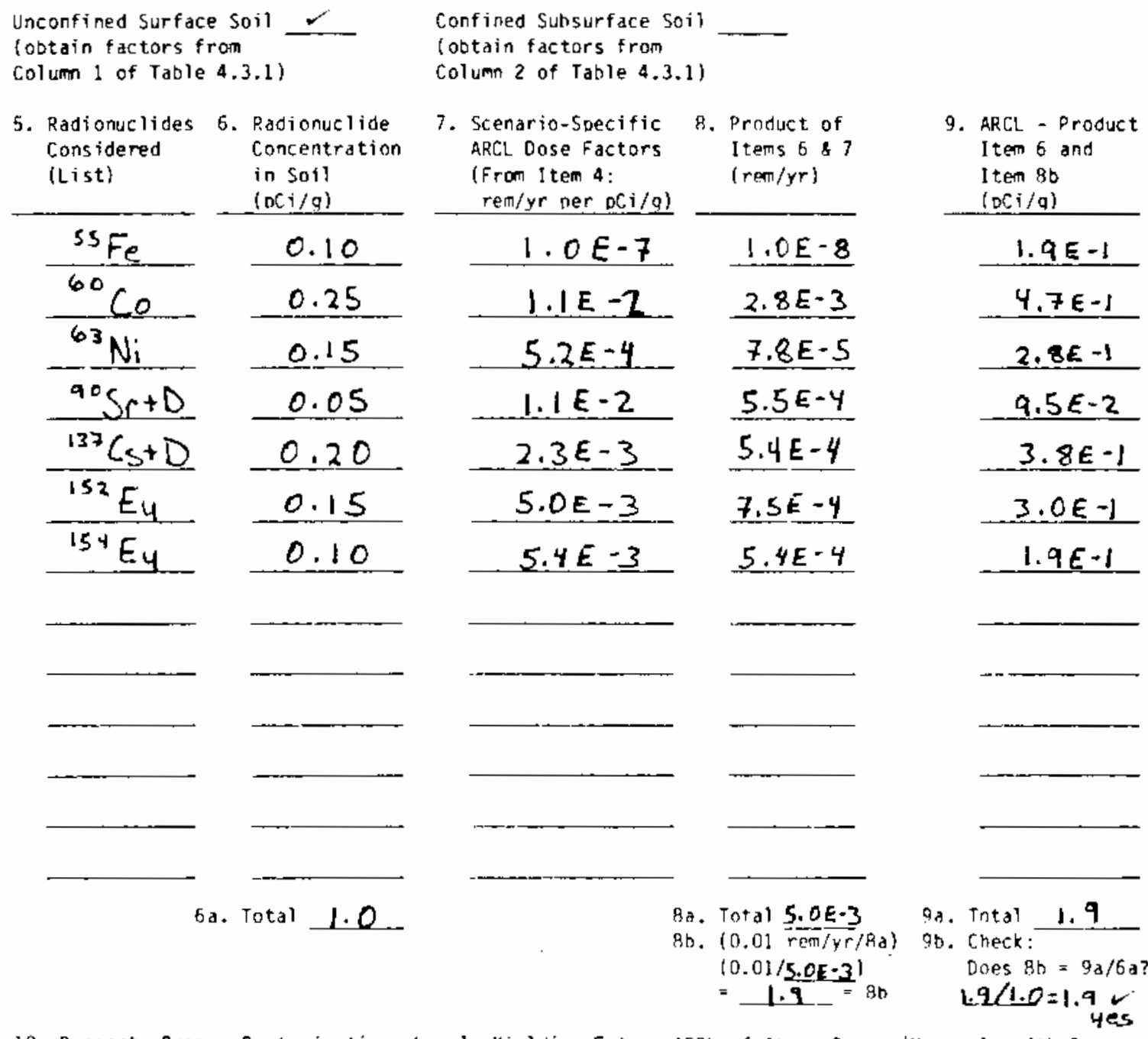

10. Present Gross Contanination Level Yielding Future ARCL of Item 9a: (Use only with necay Correction Worksheet.) (9a) NA_ $\times(9$ of Figure 4.4.4) $=$

11. Addi tional Notes:

FIGURE 4.4.2. Allowable Residual Contamination Leve1 Worksheet for Soil Contamination at the Shippingport Atomic Power Station Site - Example Problem 1 
1. Case name: Example Problem 2

2. Preparer's Name: W.E. KENNEOY, JR.

3. Date Prepared: $9 / 27 / 83$

4. Detemination of ARCL Dose Factors to Enter From Table 4.3.1. (Check One)

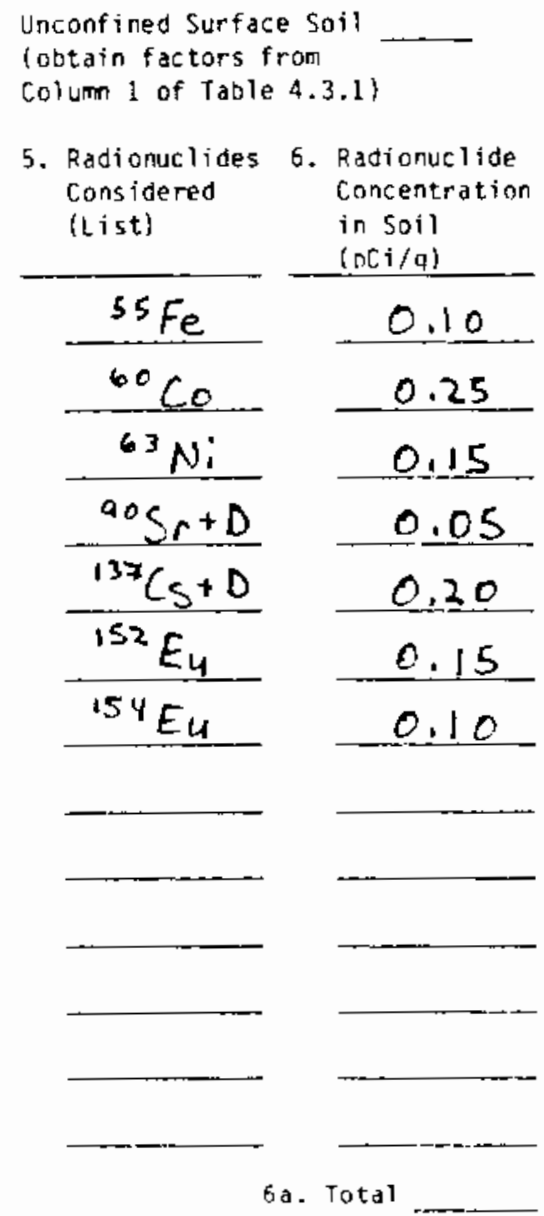

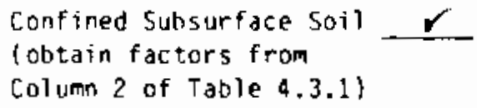

7. Scenario-Specific ARCL Dose Factors

(From Item 4: $\mathrm{rem} / \mathrm{yr}$ Der $\mathrm{pCi} / \mathrm{q})$

2.OE-8 2.OE-9

$2.2 E \cdot 3-5.5 E-4$

$1.0 E-\underline{4}$

1.5E-S.

$3.2 \epsilon-3$

$5.3 E+4$.
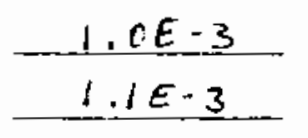

I.IE- 4

$1.1 E-4$

1.5E-4

1.1E-4

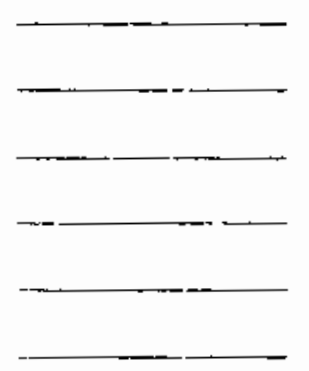

8a. Total L.OE-3

Bb. $(0.01 \mathrm{rem} / \mathrm{Vr} / \mathrm{Ra})$

$(0.01 / \underline{1} .0 E \cdot 3)$
9. ARCL - Product

I tem 6 and

1 tem $8 b$

( $0 \mathrm{C} i / q)$

1.0

$2 \cdot 5$

1.5

0.5

$2 \cdot 0$

1.5

1.0

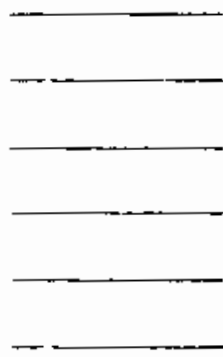

9. Total 10

9b. Check:

Does $8 \mathrm{D}=9 \mathrm{a} / 6 \mathrm{a}$ ?

$10 / 1.0=10$ $4 e^{2}=$

10. Present Gross Contanination Level Yielding Future ARCL of Item $9 a$ : (Use only with Decay Correction Horksheet.) (9a) NA $x(9$ of Figure 4.4.4) $=$

11. Additional Notes:

FIGURE 4.4.3. Allowable Residual Contamination Level Worksheet for Soil Contamination at the Shippingport Atomic Power Station Site - Example Problem 2 
total of the entries in Item 8 is entered as Item 8 a (1.1E-3 rem/yr). This is the dose in rem that an individual could receive as a result of exposure (to soil containing $1 \mathrm{pCi} / \mathrm{g}$ of the mixture) during the most restrictive combination of the residential/construction and residential/home-garden scenarios. The ratio of the annual dose limit $(0.01 \mathrm{rem})$ to Item $8 \mathrm{a}$ is shown in Item 8 b as 9.9. The resulting ARCL values are found by the product of the entries in Item 6 and Item $8 \mathrm{~b}$, and are reported in I tem 9 . The sum of the individual radionuclide $A R C L$ values in the examole mixture is shown in Item $9 \mathrm{a}$ as $9.9 \mathrm{pCi} / \mathrm{g}$. Aqain, the mathematical check indicates that no errors are contained in the worksheet calculations.

The radionuclide contributing the dominant portion of the dose in bnth example problems is $60 \mathrm{Co}$. This can be seen by insrection of the data entries in Item 8 of Figures 4.4 .2 and 4.4 .3 .

The entries in Item 6 of the worksheet are desianed to be innut as curies (or normalized activity levels) existing on the site at the time of release. If unrestricted release of the sits is to occur only after the Beaver valley 1 and 2 oower reactors are decommissioned, the radionuclide inventory from the Shippingport Atomic Power Station would have decayed to a level below that existing today. The effect of 1 imited radioactive decav on the source inventory for a mixture can be determined using the worksheet shown in Figure 4.4.4. The decayed inventory calculated using this work sheet is then used in Work sheet Figure 4.4.1 to detemine the ARCL value after limited radioactive decay. Any decay time (in years) up to about 100 years can be used in the worksheet. The following instructions explain how to use the decay correction worksheet shown in figure 4.4.4.

1. Case Name. Enter the name or numerical designation of the current case and any other identification information.

2. Preparer's Mame. Enter the name of the person preparing the decav correction worksheet.

3. Date. Enter the date on which the worksheet was completed. 
1. Case Name:

2. Preparer's Name:

3. Date:

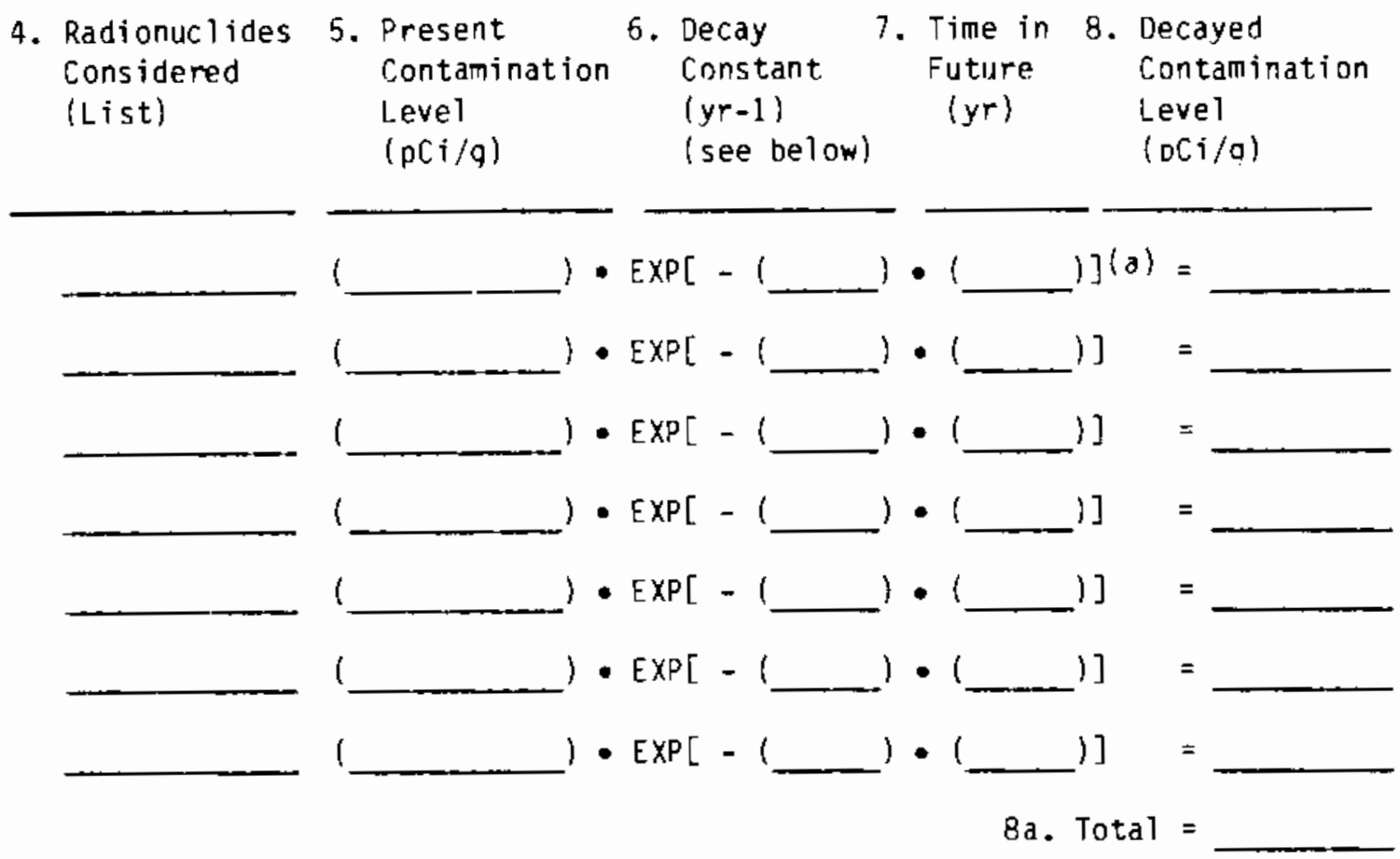

9. Ratio of Present to Future Gross Contamination Levels. Quotient of Item $5 \mathrm{a}$ and Item $8 \mathrm{a}$. $5 \mathrm{a}$. $8 \mathrm{a} .1$ $1=$

Decay Constants for Potentia1 Nuclides at the Shippingport Atomic Power Station $\left(\mathrm{yr}^{-1}\right)$

Nuclide Constant Nuclide Constant Nuclide Constant Nuclide Constant

$\begin{array}{llllllll}{ }^{3} \mathrm{H} & 5.6 \mathrm{E}-2 & { }^{63} \mathrm{Ni} & 7.5 \mathrm{E}-3 & 135 \mathrm{Cs} & 3.0 \mathrm{E}-7 & 237 \mathrm{ND}+0 & 3.2 \mathrm{E}-7 \\ { }^{14} \mathrm{C} & 1.2 \mathrm{E}-4 & 90 \mathrm{Sr}+\mathrm{D} & 2.4 \mathrm{E}-2 & 137 \mathrm{Cs}+\mathrm{D} & 2.3 \mathrm{E}-2 & 238 \mathrm{Pu} & 7.9 \mathrm{E}-3 \\ { }^{57} \mathrm{Co} & 9.3 \mathrm{E}-1 & 93 \mathrm{Mo} & 2.3 \mathrm{E}-4 & 144 \mathrm{Ce} & 8.9 \mathrm{E}-1 & 239 \mathrm{Pu} & 2.8 \mathrm{E}-5 \\ { }^{60} \mathrm{Co} & 1.3 \mathrm{E}-1 & 99 \mathrm{TC} & 3.2 \mathrm{E}-6 & 152 \mathrm{Eu} & 5.0 \mathrm{E}-2 & 241 \mathrm{Am} & 1.6 \mathrm{E}-3 \\ { }^{55} \mathrm{Fe} & 2.6 \mathrm{E}-1 & 124 \mathrm{Sb} & 4.2 \mathrm{E}+0 & 154 \mathrm{Eu} & 8.9 \mathrm{E}-2 & & \\ { }^{59} \mathrm{Fe} & 5.6 \mathrm{E}+0 & 125 \mathrm{Sb}+\mathrm{D} & 2.5 \mathrm{E}-1 & 235 \mathrm{U}+\mathrm{D} & 9.8 \mathrm{E}-10 & & \\ { }^{59} \mathrm{Ni} & 8.7 \mathrm{E}-6 & 134 \mathrm{Cs} & 3.4 \mathrm{E}-1 & 238 \mathrm{U}+\mathrm{D} & 1.5 \mathrm{E}-10 & & \end{array}$

(a) The notation EXP $[-(a)(b)]$ means the exponential, e-ab

FIGURE 4.4.4. Allowable Residual Contamination Level Radioactive Decay Correction Worksheet 
4. Radionuclides Considered. Enter the radionuclides considered in the space provided. If additional space is renuired, use additional work sheets.

5. Present Contamination Level. Enter the present source inventnry in units of $\mathrm{DCi} / \mathrm{g}$ for soils. This inventory is the $\mathrm{T}=0$ inventory and can be given in relative or absolute amounts.

6. Decay Constant. Enter the decay constant $\left(y r^{-1}\right)$ for each radionuclide in the source inventory. A list of decay constants is shown at the bottom of the worksheet.

7. Time in the Future. The number of years of radioactive decay considered should be entered in Item 7. Note: The same number of years should be entered for each radionuclide.

8. Decayed Contamination Level. The negative exponential of the product. of the entries in Items 6 and 7 is then multiplied by the entries in Item 5 and renorted in Item $\&$ as the decayed contamination level. This level should be totaled in Item $8 a$ and entered in the ARCL Worksheet (Figure 4.4.1) to determine the decayed ARCL value for the specific time in the future considered.

As an examole of the use of the decay correction worksheet, the soil contamination inventory of Example Problem 1 is used with an assumed recay period of 50 years. The value of 50 years is assined to approximate the potential operating 1 ifetime plus the time required for decommissioning of the Beaver valley reactors. Figure 4.4 .5 shows the resulting decay calculations as Exambie Problem 3. The decayed contamination level is $0.19 \mathrm{pCi} / \mathrm{a}$ in soil. This decayed level is used in the ARCL Worksheet to determine the unrestricted ARCL value for surface sof 1 after 50 years of radioactive decay (as shown in Figure 4.4.6). Item 10 of the worksheet shows the present gross contamination level that results in the ARCL after 50 years of radioactive decay. This value is about $23 \mathrm{pCi} / \mathrm{g}$.

The impact of radioactive decay for 50 years on the ARCL calculations can be determined by comparing the results of Example Problems 1 and 3 (see 
1. Case Name: Example Problem 3

2. Preparer's Name: W.E. Kenjescr, Ja.

3. Date: $9 / 27 / 83$

4. Radionuclides Considered

(List)
5. Present Contamination Level $(\mathrm{pCi} / \mathrm{g})$
6. Decay Constant $(y r-1)$ (see below)
7. Time in 8. Decayed Future (yr) Level Contamination $(D C i / g)$

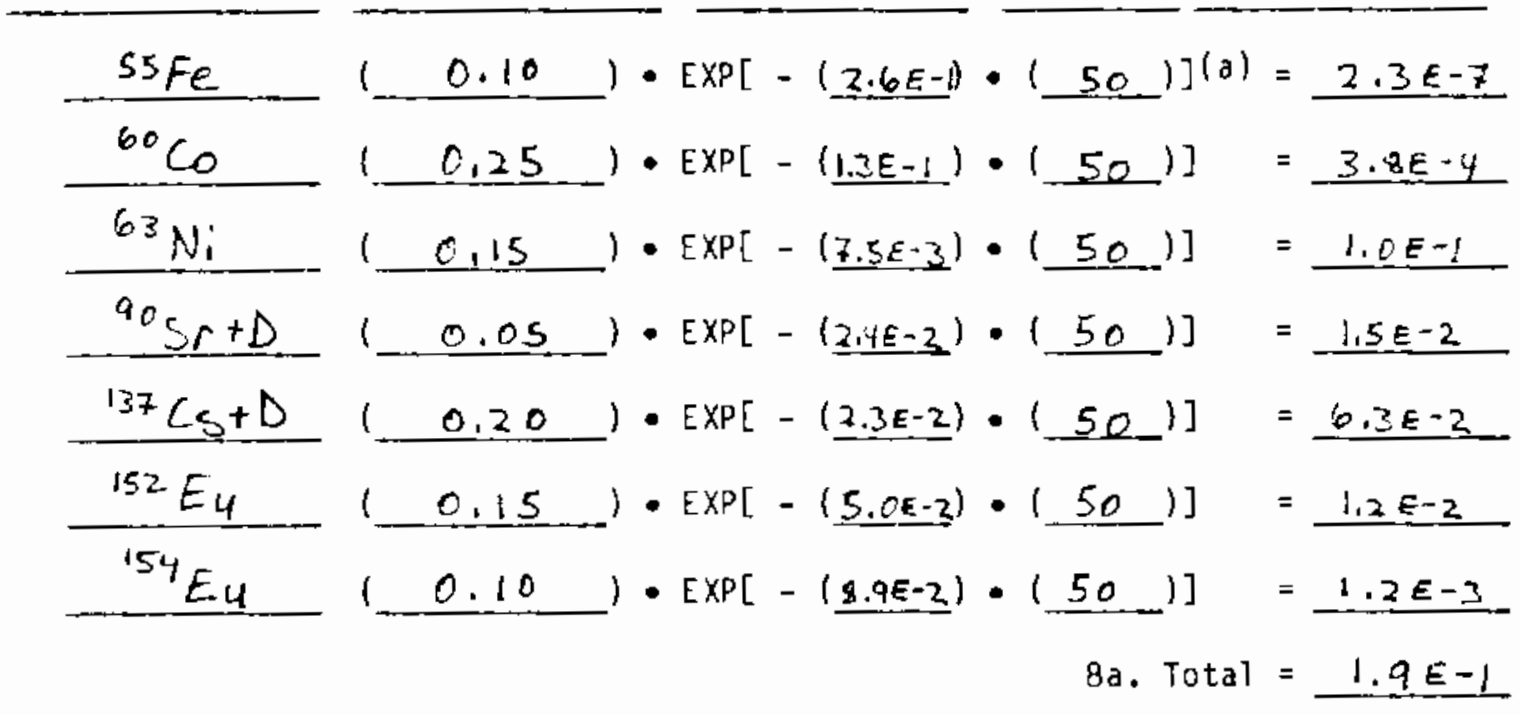

9. Ratio of Present to Future Gross Contamination Leveis. Quotient of Item $5 \mathrm{a}$ and 1 tem $8 \mathrm{a}$. $5 \mathrm{a} \cdot(1.0) 8 \mathrm{a} \cdot(\underline{1.9 E-1})=\underline{5.2}$

Decay Constants for Potential Nuciides at the Shipoingport Atomic Power Station (yr-1)

Nuclide Constant Nuclide Constant Muclide Constant Nuclide Constant

$\begin{array}{llllllll}{ }^{3} \mathrm{H} & 5.6 \mathrm{E}-2 & { }^{63} \mathrm{Ni} & 7.5 \mathrm{E}-3 & 135 \mathrm{Cs} & 3.0 \mathrm{E}-7 & 237 \mathrm{~Np}+\mathrm{D} & 3.2 \mathrm{E}-7 \\ { }^{14} \mathrm{C} & 1.2 \mathrm{E}-4 & 90 \mathrm{Sr}+\mathrm{D} & 2.4 \mathrm{E}-2 & 137 \mathrm{CS}+\mathrm{D} & 2.3 \mathrm{E}-2 & 238 \mathrm{Pu} & 7.9 \mathrm{E}-3 \\ { }^{57} \mathrm{Co} & 9.3 \mathrm{E}-1 & 93 \mathrm{MO} & 2.3 \mathrm{E}-4 & 144 \mathrm{Ce} & 8.9 \mathrm{E}-1 & 239 \mathrm{Pu} & 2.8 \mathrm{E}-5 \\ { }^{60} \mathrm{CO} & 1.3 \mathrm{E}-1 & { }^{99} \mathrm{TC} & 3.2 \mathrm{E}-6 & 152 \mathrm{Eu} & 5.0 \mathrm{E}-2 & 241 \mathrm{Am} & 1.6 \mathrm{E}-3 \\ { }^{55} \mathrm{Fe} & 2.6 \mathrm{E}-1 & 124 \mathrm{Sb} & 4.2 \mathrm{E}+0 & 154 \mathrm{Eu} & 8.9 \mathrm{E}-2 & & \\ { }^{59} \mathrm{Fe} & 5.6 \mathrm{E}+\mathrm{O} & 125 \mathrm{Sb}+\mathrm{D} & 2.5 \mathrm{E}-1 & 235 \mathrm{U}+\mathrm{D} & 9.8 \mathrm{E}-10 & & \\ { }^{59} \mathrm{Ni} & 8.7 \mathrm{E}-6 & 134 \mathrm{CS} & 3.4 \mathrm{E}-1 & 238 \mathrm{U}+\mathrm{D} & 1.5 \mathrm{E}-10 & & \end{array}$

(a) The notation EXP $[-(a)(b)]$ means the exponential, e $e^{-a b}$

FlGURE 4.4.5. Allowable Residual Contamination Level Radioactive Decay Correction Worksheet - Example Problem 3 
1. Case Name: Example Proglem 3

2. Preparer's Name: W.E. KenNeDY, Je.

3. Date Prepared: $9 / 27 / 83$

4. Determination of ARCL Dose Factors to Enter From Table 4.3.1. (Check nne)

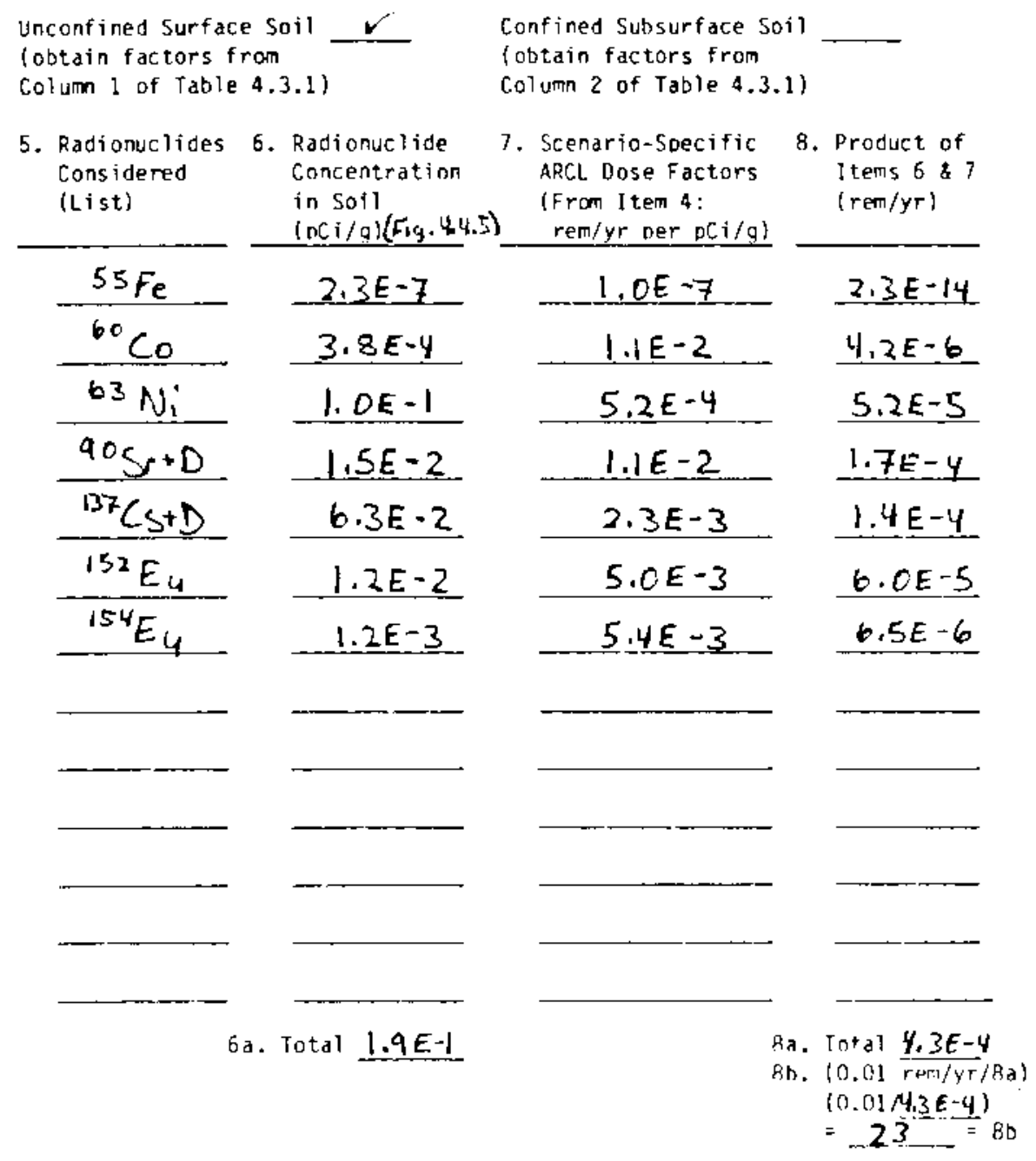

Confined Subsurface soil

Cobtain factors from

Column 2 of Table 4.3 .1

10. Present Gross Contamination Level Yielding Future ARCL of Item $9 a$ :

9. ARCL - Product Item 6 and I tem $8 \mathrm{~b}$ $(0 \mathrm{C} i / 9)$

$5.3 E-6$ $8.9 \varepsilon-3$ $2 \cdot 3 E+0$ $3.5 E-1$ $1.4 E+0$ $2.8 E-1$ $2.8 E-2$ a. intal 4.4 9b. Cheik: Does $8 \mathrm{~b}=9 \mathrm{a} / 6 \mathrm{a}$ ? $4.4 / 0.19=23$ yes - Additional Notes:

FIGURE 4.4.6. Allowable Residual Contamination Level Worksheet for Soil Contamination at the Shippingport Atomic Power Station Site - Example Problem 3 
Fiqures 4.4.2 and 4.4.6). In these examples, at $T=0$, the ARCL is controlled by ${ }^{60} \mathrm{Co}$, but after 50 years of decay, the ARCL is controlled by the longer-lived ${ }^{90} \mathrm{~S} r+D$ and ${ }^{137} \mathrm{Cs}+\mathrm{D}$. The $\mathrm{ARCL}$ for the mixture at $T=0$ is 1.9 $\mathrm{pCi} / \mathrm{g}$, while at $T=50$, the value is $4.4 \mathrm{pCi} / \mathrm{g}$. The present gross contamination level that will decay to the ARCL at 50 years $(4.4 \mathrm{pCi} / \mathrm{g})$ is $23 \mathrm{pCi} / \mathrm{g}$. Again, this calculation can be performed for any radioactive decay period with compliance to any annual dose limit. 


\subsection{DISCUSSION OF RESULTS}

The method described in this document for determining the Allowable Residual Contamination Levels (ARCL) of radionuclides remaining in the soil at the Shippingoort Atomic Power Station is based on a scenario/exposurepathway analysis and compliance with an annual dose 1 imit. ARCL results are presented for each of 29 individual radionuclides that could potentially be present in the soil at any time after decommissioning. These results are based on an example annual dose of $10 \mathrm{mrem} / \mathrm{yr}$ to an individual residing on the site after decommissioning. ARCL values based on any other annual dose 1 imit can be found by direct ratio. In develooing the residential exposure scenarios, we have el iminated from consideration individuals who may have occasional exposures as would occur if the site were used as a recreational area or park. We have al so based the result on home-gardening activities which might not occur if the site were used onty for industrial purposes. However, the residential scenarios are seen as beina reoresentative of the more 1 imiting conditions that could be encountered during unrestricted use.

The method and results presented are intended to be flexible ennugh to use the detailed soil contamination information obtained during the onst.decomissioning survey to determine if unrestricted-use release conditions can be met. This is accomplished by using the worksheets provided in Section 4.0. These work sheets Dermit use of the ARCL dose conversion factors with the specific radionuclide mixtures and concentrations determined at the Shippingport Site. In addition, the worksheets permit calculation of the ARCL value at any specified future time, following ratioactive decay and translation of this ARCL value to permissible soil concentrations at present time. The worksheets also permit substitution of any dose $1 \mathrm{imit}$; however, $10 \mathrm{mrem} / \mathrm{yr}$ is used for the examnle oroblems shown to demonstrate the ARCL method.

The ARCL results are presented for both unconfined (surface) and confined (subsurface) soil contamination conditions. While several subsurface soil conditions are nossible, we have chosen to model only the case 
where clean snil is used to fill over contaninated soil. This condition results in a more limiting result than if a solid or "packaged" waste form were encountered instead of homogeneous soil contamination. We have considered soil contamination only since the site should not have the required restrictions associated with a 10 -level radioactive wasto burial ground.

For the residential/home-garden scenario, the most restrictive radionuclides determined in this study are $90 \mathrm{Sr}$ (plus its short-lived dauohter $90 \mathrm{y}$ ) and 60co. These radionuclides have the lowest soil concentrations (in $\mathrm{pCi} / \mathrm{g})$ that result in $10 \mathrm{mrem} / \mathrm{yr}$, as shown in Table 4.3.2. For unconfined soil, the ARCL for each of these radionuclides is $0.91 \mathrm{pCi} / \mathrm{g}$. The critical exposure pathway for $90 \mathrm{Sr}$ is ingestion of garden products and the critical organ is bone. For ${ }^{60} \mathrm{Co}$, the critical exposure pathway is direct exposure from denetrating (gama) radiation and the critical organ is total body.

In this study we considered soil contamination only. In nractice, structural building materials containing surface contamination may be left buried in the soil at a site. Thus, a method is needed to convert surfacecontaraination levels to volume-contamination levels for comnarison with the ARCL values for soil. This can he done by using the radiologicai survey data (in dpm/100 $\mathrm{cm}^{2}$ or $\left.\mathrm{Ci} / \mathrm{m}^{2}\right)$, an estimate of total contaminated surface area ( $\mathrm{cm}^{2}$ or $\left.\mathrm{m}^{2}\right)$, and enqineering data about the volume and mass of rubbla to be buried. For examnle, consider the surface contamination assnciated with a wall in a buildinn. The contamination level times the total contaminated surface area of the wall will give an estimate nf the total Ci of contamination surface area of the wall will give an estimate of the total $\mathrm{Ci}$ of contamination present. This value, divided by the anoroximate mass of the wall, can be used to give a $\mathrm{pCi} / \mathrm{g}$ estimate which can be directly compared to the unconfined or confined soil ARCL values. This method does not account for further dilution of the radionuclides in soil and it assumes homogeneous mixing with all materials in the wal1; however, it does provide a working estimate of the notential concentrations of material to be buried wi thout taking undue credit for dilution with clean rubble or soil. 
The ARCL method and results described in this report provide a flexible means of considering the radioactive contamination conditions at the Shippingport Atomic Power Station in deternining unrestricted-use release conditions. 


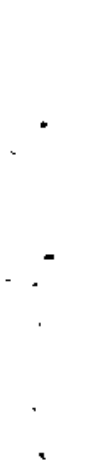




\subsection{REFERENCES}

Anspaugh, L. R., J. H. Shinn, P. L. Phelps and N. C. Kennedy. 1975. "Resuspension and Redistribution of Plutonium in Soils." Health Phys. $29: 571-582$.

Code of Federal Regulations. Title 10, Part 20, "Standards for Protection Against Radiation."

Code of Federal Regulations. Title 40, Part 190, "Environmental Protection Standards for fuclear Power operations."

Code of Federal Regulations. Title 40, Part 192, "Environmental Protection Standards for Uranium Mill Tailings."

Duquesne Light Company. 1972, 1974-1979, and 1982. Annual Environmental Report. Duquesne Light Company, Beaver Valley Power Station and Shipoingport Atomic Power Station, Shippingoort, Pennsylvania.

Eckeman, K. F. and M. W. Young. 1980. A Methodology for Calculating Residual Radioactivity Levels Following Decommissioning. NUREG-0707. U.S. Nuclear Regulatory Commission, Washington, D.C.

Federal Register, Vol. 46, No. 27. 11666-68(February 10,1981). "Nuclear Regulatory Comnission, 10 CFR Parts 30,40,50,70 and 72, Decommissioning Criteria for Nuclear Facilities; Notice of Availability of Draft Environmental Impact Statement," Washington, D.C.

Federal Register, Vol. 48, No. 3. 590-606(January 5, 1983). "Environmental Protection Agency, 40 CFR Part 192, Standards for Remedial Actions at Inactive Uranium Proecssing Sites - Final Rule." Washington, D.C.

Healy, J. W. 1974. A Proposed Interim Standard for Plutonium in Soils. LA-5483-MS, Los Alamos Scientific Laboratory, Los Alamos, New Mexico.

healy, J. W., J. C. Rodgers and C. L. Wienke. 1979. Interim Soil Limits for D\&0 Projects. LA-UR-79-1865-Rev., Los Alamos Scientific Laboratory, Los Alamos, New Mexico.

Houston, J.R., 0. L. Strenge, and E. C. Watson. 1976. DACRIN - A Computer Program for Calculating Organ Doses from Acute or Chronic Radionuclide Inhalation. BNWL-B-389, Pacific Northwest Laboratory, Richland, Washington. 
International Commission on Radiological Protection (ICRP). 1966. "Deposition and Retention Models for Internal Dosimetry of the Human Respiratory Tract." Health Phys. 12:173-207.

Kennedy, W. E., Jr., E. C. Watson, G. R. Hoenes, and B. A. Napier. 1979. "A Method for Determining Acceptable Residual Radioactive Contamination Leve1s." Paper oresented at the 24th Annual Meeting of the Health Physics Society, July 8-13, 1979, Philadelphia, Pennsylvania.

Kennedy, W. E., Jr., R. L. Aaberg, B. A. Napier, and J. K. Soldat. 1982. Transuranic Advanced Disposal Systems: Preliminary Pu Waste Disposal Criteria for Hanford. PNL-4254. Pacific Northwest Laboratory, Richland, Washington.

Kennedy, W. E., Jr., B. A. Napier and J. K. Soldat. 1983. "Advanced Disposal Systems for Transuranic Waste: Preliminary Disposal Criteria for Plutonium-239 at Hanford." Nuc. Chem. Waste Mgt., 4(1):103-111.

Konzek, G. J., J. D. Ludwick, W. E. Kennedy, Jr., and R. I. Smith. 1981. Technology, Safety and Costs of Decommissioning Reference Nuclear Research and Test Reactors. NUREG/CR-1756, prepared for the U.S. Nuc Tear Regulatory Commission by Pacific Northwest Laboratory, Richland, Washington.

Logsdon, J. E., and R. I. Chissler. 1970. Radioactive Waste Discharges to the Environment From Nuclear Power Facilities. BR.H/DER 70-2. U.S. Department of Health, Education, and Welfare, Bureau of Radiological Health, Rockville, Maryland.

Mueller, M. A., H. E. Kennedy, Jr., and J. K. Soldat. 1981. Review of Soi] Contamination Guidance. PNL-3866. Pacific Northwest Laboratory, Richland, Washington.

Murphy, E. S., and G. M. Holter. 1980. Technology, Safety and costs of Decommissioning a Reference Low-Level waste Burial Ground. NUREG/CR-0570, Vols. 1 and 2, report prenared for the Nuclear Regulatory Commission by Pacific Northwest Laboratory, Ricbland, Washinaton.

Napier, B. A., G. R. Hoenes, W. E. Kennedy, Jr., and E. C. Watson. 1979. "The laximum Annual Dose Resulting from Residual Radioactive Contamination." Paper presented at the 24 th Annual Meeting of the Health Physics Society, July 8-13, 1979, Philadelphia, Pennsyivania. Pacific Northwest Laboratory, Richland, Washington. 
Napier, B. A., R. L. Roswe11, W. E. Kennedy, Jr., and D. L. Strenge. 1980. ARRRG and FOOD - Computer Programs for Calculating Radiation Dose to Man from Radionuclides in the Environment. PNL-3180, Pacjfic Northwest Laboratory, Richland, Washington.

Napier, B. A. 1982. A Method for Determining "Allowable Residual Comtamination Levels" of Radionuclide Mixtures in Soil. PNL-3852. Pacific Northwest Laboratory, Richland, Washington.

Oak, H. D., G. M. Holter, W. E. Kennedy, Jr., and G. J. Konzek. 1980. Technology, Safety and Costs of Decommissioning a Reference Boiling-Water Reactor Power Station. NUPEG/CR-0672, Vol. 1 and 2, prepared for the U.S. Nuclear Regulatory Commission by Pacific Northwest Laboratory, Richland, Washington.

Schneider, J.K. and C. E. Jenkins. Technology, Safety, and Costs of Decommissioning a Reference Nuclear Fuel Reprocesing P1ant. NUREG-0278. Prepared for the U.S. Nuclear Regulatory Commission by Pacific Northwest Laboratory, Richland, Washington.

Smith, R. I., G. J. Konzek and W. E. Kennedy, Jr. 1978. Technology, Safety, and Costs of Decommissioning a Reference Pressurized water Reactor Power Station. NUREG/CR-0130, Vol. 1 and 2, prepared for the U.S. Nuclear Regulatory Commission by Pacific Northwest Laboratory, Richland, Washington.

U.S. Atomic Energy Commission. 1974. Termination of Operating Licenses for Nuclear Reactors. Regulatory Guide 1.86, Directorate of Regulatory Standards, Washington, D.C.

U.S. Department of Health, Education and Welfare. 1960-1965. Radiological Health Data. Vols. 1-6. U.S. Department of Health, Education, and Welfare, Division of Radiological Health, Washington, D.C.

U.S. Department of Health, Education and Welfare. 1966-1972. Radiological Health Data and Reports. Vols. 7-12, Division of Radiological Health, Washington, D.C.

U.S. Department of Energy 1982. Final Environmental Impact Statement, Decommissioning of the Shipningport Atomic Power Station. DOE/EIS-000F, Washington, D.C.

U.S. Environmental Protection Agency. 1972-1974. Radiation Data and Reports. Vols. 13-15, of fice of Radiation Programs, washington, D.C. 
U.S. Energy Research and Development Agency. 1976. Final Environmental Impact Statement, Light Water Breader Program. ERDA 1541, Vols. 1-5. washington, D.C.

U.S. Nuclear Regulatory Commission. 1976. Guidelines for Decontamination of Facilities and Equipment Prior to Release for Unrestricted Use or Termination of Licenses for By-Product, Source, or Snecial Nuclear Material. Washington, D.C.

U.S. Nuclear Regulatory Commission. 1981. Draft Environmental Impact Statement on 10 CFR Part 61, "Licensing Requirements for Land Disposal of Radjoactive Waste." NUREG-0782, Vols. 1-4, Washington, D.C.

U.S. Nuclear Requlatory Commission. 1982. Fina? Environmental Impact Statement on 10 CFR Part 61 "Licensing Requirements for Land Disposal of Radioactive Waste." NUREG-0945. Washington, D.C. 
PNL-4801

RL/SFM-83-9

UC- $70 \mathrm{~A}$

DISTRIBUTION

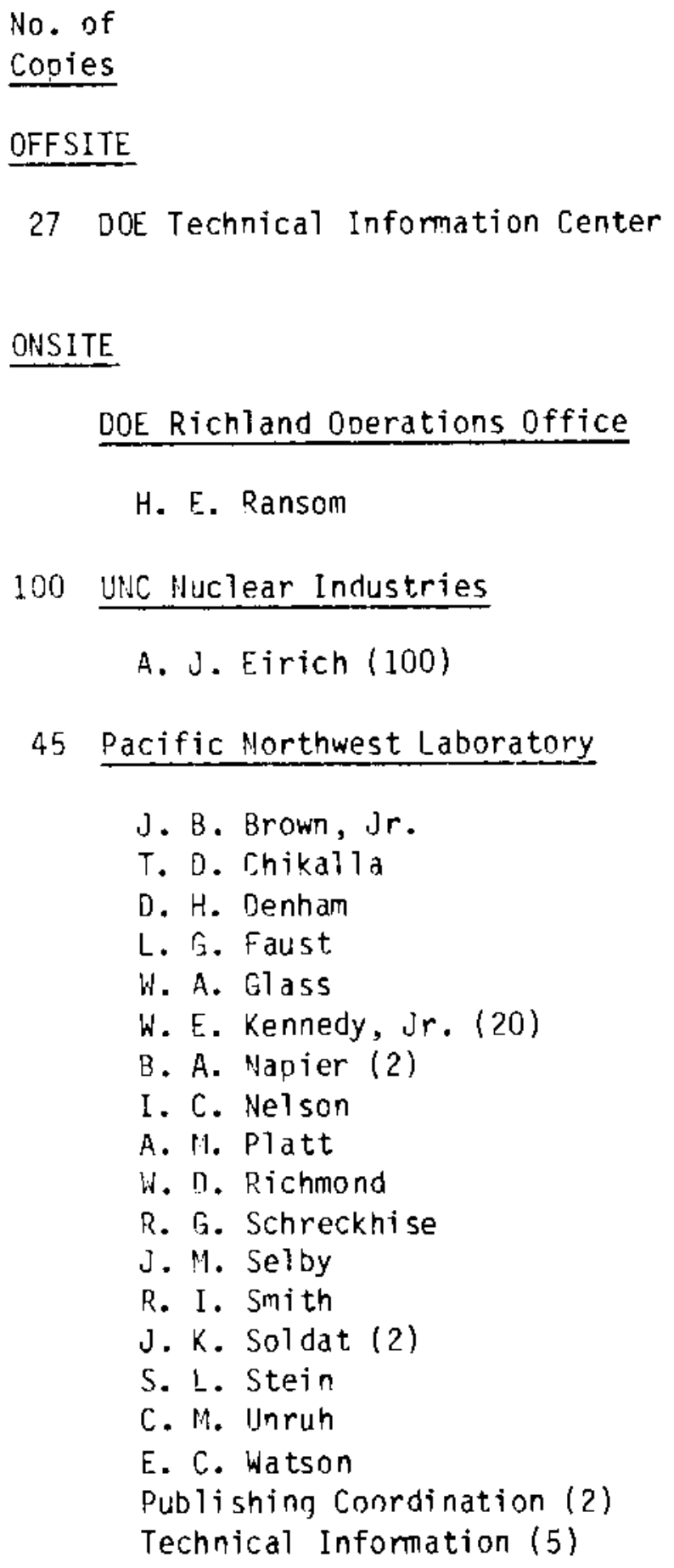




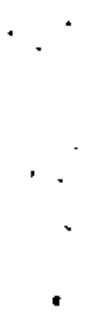

, 